\title{
The dizinc bond as a ligand: a computational study of elongated dizinc
}

bonds.

Regla Ayala ${ }^{\mathrm{a}, \mathrm{b}}$ *, Ernesto Carmona ${ }^{\mathrm{a}, \mathrm{c}}$, Agustín Galindo *

${ }^{a}$ Departamento de Química Inorgánica, Facultad de Química, Universidad de Sevilla, Aptdo 1203, 41071 Sevilla, Spain.

${ }^{b}$ Instituto de Ciencia de Materiales de Sevilla-CSIC. Avda. Américo Vespucio 49, 41092 Sevilla, Spain.

${ }^{c}$ Instituto de Investigaciones Química de Sevilla-CSIC. Avda. Américo Vespucio 49, 41092 Sevilla Spain.

E-mail addresses: rae@us.es, galindo@us.es

Dedicated to our colleague and friend Professor Carlo Mealli, who introduced to some of us to the "busilis" of theoretical chemistry. 


\section{ABSTRACT}

Following the synthesis of $\left[\mathrm{Zn}_{2}\left(\eta^{2}-\mathrm{C}_{5} \mathrm{Me}_{5}\right)_{2}\right]$ (in short $\left[\mathrm{Zn}_{2} \mathrm{Cp}_{2}{ }_{2}\right]$ ) many complexes of the directly bonded $\mathrm{Zn}-\mathrm{Zn}$ unit were prepared and characterized, leading to the recognition of an isolobal analogy between the $\mathrm{Zn}-\mathrm{Zn}$ bond and the molecule of dihydrogen. Prompted by these results, we have investigated $\eta^{2}-Z_{2}$-coordination of $\left[\mathrm{Zn}_{2} \mathrm{Cp}_{2}\right]$ and $\left[\mathrm{Zn}_{2} \mathrm{Ph}_{2}\right]\left(\mathrm{Cp}=\mathrm{C}_{5} \mathrm{H}_{5}, \mathrm{Ph}=\right.$ $\mathrm{C}_{6} \mathrm{H}_{5}$ ) to several selected transition metal fragments and report herein the results of a QTAIM study of complexes $\left[(\mathrm{ZnR})_{2} \mathrm{Fe}(\mathrm{CO})_{4}\right],\left[\left(\eta^{2}-\mathrm{Zn}_{2} \mathrm{R}_{2}\right) \mathrm{M}(\mathrm{CO})_{5}\right]$ and $\left[\left(\eta^{2}-\mathrm{Zn}_{2} \mathrm{R}_{2}\right) \mathrm{Pd}\left(\mathrm{PR}_{3}\right)_{2}\right]$ (for $\mathrm{R}$ $=\mathrm{Cp}, \mathrm{Ph} ; \mathrm{M}=\mathrm{Cr}, \mathrm{Mo}, \mathrm{W}$; and $\left.\mathrm{R}^{\prime}=\mathrm{F}, \mathrm{H}, \mathrm{Me}\right)$. A decrease of $\rho_{\mathrm{BCP}}, \nabla^{2} \rho_{\mathrm{BCP}}$ and delocalization indexes $\delta(\mathrm{Zn}, \mathrm{Zn})$, relative to corresponding values in the parent molecules of $\left[\mathrm{Zn}_{2} \mathrm{Cp}_{2}\right]$ and $\left[\mathrm{Zn}_{2} \mathrm{Ph}_{2}\right]$, accompanied dizinc coordination. In most cases the computed $\delta(\mathrm{Zn}, \mathrm{Zn})$ parameters were indicative of significant electron density sharing between the two $\mathrm{Zn}$ atoms. Nevertheless, the interaction with $\left[\mathrm{Fe}(\mathrm{CO})_{4}\right]$ resulted in oxidative cleavage of the coordinated $\mathrm{Zn}-\mathrm{Zn}$ bond, due to high $\pi$ backdonation to the $\sigma^{*} \mathrm{Zn}_{2} \mathrm{MO}$ as deduced from the $\delta\left(\mathrm{M}, \mathrm{O}_{\mathrm{CO}}\right)$ index. The $\mathrm{Zn}-\mathrm{Zn}$ bond critical points identified in our study are discussed. The computed $\mathrm{Zn}-\mathrm{Zn}$ contacts concentrate in the range 2.44-2.58 $\AA$, and we propose that this interval corresponds to elongated dizinc bonds.

Keywords: zinc; DFT; QTAIM; dizinc; organometallic complexes; cyclopentadienyl 


\section{Introduction}

The isolation and characterization of complex $\left[\mathrm{Zn}_{2} \mathrm{Cp}^{*}{ }_{2}\right] \mathbf{1}\left(\mathrm{Cp}^{*}=\eta^{5}-\mathrm{C}_{5} \mathrm{Me}_{5}\right)[1,2]$ displaying a directly bonded dizinc $\mathrm{Zn}(\mathrm{I})-\mathrm{Zn}(\mathrm{I})$ unit, opened a new chapter in the chemistry of this element $[3,4]$. A good number of theoretical and experimental studies followed the synthesis of this compound [5,6,7], providing a clear picture of the, until then, unknown $\mathrm{Zn}$ Zn bond [8], and expanding significantly the number of well-defined complexes of this sort [9,10,11]. In general, the $\mathrm{Zn}(\mathrm{I})-\mathrm{Zn}(\mathrm{I})$ moiety of these molecules is kinetically stabilized toward disproportionation to $\mathrm{Zn}(0)$ and $\mathrm{Zn}(\mathrm{II})$ by the presence of substituted cyclopentadienyl rings [2], bulky terphenyl groups [9], or a variety of chelating $\mathrm{N}$-donor ligands [12]. A notable exception is the isolation of the dication $\left[\mathrm{Zn}_{2}\right]^{2+}$ containing only substituted pyridines as ligands [13] or $\mathrm{GaCp}^{*}$ fragments [14]. Comparatively less attention has been paid to disclose the chemical reactivity of these molecules, though complex $\mathbf{1}$ has been used precursor for other $\mathrm{Zn}-\mathrm{Zn}$ bonded compounds [15], in catalytic hydroamination reactions [16], as well as for the synthesis of metal-rich compounds and clusters [17,18]. Fischer, Frenking and coworkers have identified a variety of $\mathrm{M}-\mathrm{ZnCp}$ * and $\mathrm{M}-\mathrm{Zn}-\mathrm{ZnCp}$ * fragments and have highlighted the isolobal analogy of $\mathrm{ZnCp}^{*}$ and $\mathrm{ZnR}$ with the $\mathrm{H}$ atom. The use of $\mathrm{ZnCp} *$ and other organozinc ligands in transition metal chemistry has also been reviewed [19].

In accordance with the quantum theory of atoms in molecules (QTAIM) [20], the topological analysis of the electron density $(\rho)$ estimated at the bond critical point (BCP) provides fingerprints revealing the nature of the atomic interactions. Bonds between atoms may be divided into two categories on the basis of the sign of laplacian $\nabla^{2} \rho_{\mathrm{BCP}}$ : shared and closed shell interactions have negative and positive $\nabla^{2} \rho_{\mathrm{BCP}}$, respectively. In shared interactions the bond electronic charge concentrates in the internuclear region and $\rho_{\mathrm{BCP}}$ has a high value, whereas closed shells are characterized by low $\rho_{\mathrm{BC}}$ values in the interatomic surfaces. On the basis of this simple classification, the first type refers to covalent or covalent polar bonds, while the second is associated with ionic bonds, hydrogen bonds and van der Waals interactions. In addition, it has been proposed [21] that local energetic parameters like the kinetic energy density G(r), the potential energy density V(r) and the total energy density $\mathrm{H}(\mathrm{r})=\mathrm{G}(\mathrm{r})+\mathrm{V}(\mathrm{r})$, also play an important role in the characterization of atomic interactions. In this way, when comparing closed shells and shared interactions, it is advisable to use the kinetic energy per electron $\mathrm{G}_{\mathrm{BCP}} / \rho_{\mathrm{BCP}}$. Closed shells interactions generally exhibit $\mathrm{G}_{\mathrm{BCP}} / \rho_{\mathrm{BC}}>$ 1 , while shared interactions have $\mathrm{G}_{\mathrm{BCP}} / \rho_{\mathrm{BCP}}<1$. 
As already pointed out [22], interpretation of bonds when heavy atoms (those with more than three atomic shells) are involved is not straightforward. Heavy atoms are characterized by diffuse electron densities, giving rise to low electron densities and concentrations in the bonding region. This usually complies with very low $\rho_{\mathrm{BCP}}$ and $\nabla^{2} \rho_{\mathrm{BCP}}$ values which rules out the use of $\nabla^{2} \rho_{\mathrm{BC}}$ for a bonding classification. Espinosa et al. [23] proposed a classification based on the adimensional $\left|\mathrm{V}_{\mathrm{BCP}}\right| / \mathrm{G}_{\mathrm{BCP}}$ ratio, introducing the concept of bond degree $(\mathrm{BD})$ as $\mathrm{BD}=\mathrm{H}_{\mathrm{BCP}} / \rho_{\mathrm{BCP}}$, for the characterization of bond types. They divided atomic interactions into three categories. Region I corresponds to pure closed shells, where $\left|\mathrm{V}_{\mathrm{BCP}}\right| / \mathrm{G}_{\mathrm{BCP}}<1$, implying that $\nabla^{2} \rho_{\mathrm{BCP}}>0$ and $\mathrm{H}_{\mathrm{BCP}}>0$. Region III refers to pure shared shells, with $\left|\mathrm{V}_{\mathrm{BCP}}\right| / \mathrm{G}_{\mathrm{BCP}}>2$ and therefore $\nabla^{2} \rho_{\mathrm{BC}}<0$ and $\mathrm{H}_{\mathrm{BCP}}>0$. Region II is then a transit region, with $1<\left|\mathrm{V}_{\mathrm{BCP}}\right| / \mathrm{G}_{\mathrm{BCP}}>2$ and $\nabla^{2} \rho_{\mathrm{BCP}}>0$ and $\mathrm{H}_{\mathrm{BCP}}<0$. In region $\mathrm{I}$, the $\mathrm{BD}$ parameter is positive and gives an idea of the non-covalent interaction, such that the larger its value, the more closed and weaker in nature is the interaction. Conversely, in regions II and III the BD parameter is negative and measures covalency. Hence, the greater its magnitude, the more covalent and stronger the bond is. This classification was followed by Gervasio et al. to describe metal-metal bonding in polynuclear complexes [24]. The bond ellipticity $\left(\varepsilon_{\mathrm{BCP}}\right)$ is another interesting parameter to be analyzed. The ellipticity measures the extent to which electron density is preferentially accumulated in a given plane containing the bond path. It is calculated as suggested by Bader et al. [25] for the quantitative description of the electron density deviation from the cylindrical symmetry in the BCP. In fact, the value of $\varepsilon_{\mathrm{BCP}}$ is a measure of the $\pi$-component of the bonding [25].

Macchi et al. [22a,26] proposed to consider in addition the integrated properties within atomic basins. The most interesting clues are the delocalization index for a pair of atoms, $\delta(\mathrm{A}, \mathrm{B})$, and the electronic density integrated over the whole interatomic surface, $\int_{\mathrm{A} \cap \mathrm{B}} \rho$. The former hints the number of electron pairs that are exchanged or shared between two atomic basins and can be interpreted as the covalent bond order if identical atoms are considered. These basins need not have a common interaction surface, so that the index may be computed for any pair of atoms, regardless of whether or not they are formally bonded. Delocalization indexes are typically related to bonding mechanism and only indirectly to the interaction strength, which is revealed by the value of $\int_{\mathrm{A} \cap \mathrm{B}} \rho$. Bonds between heavy atoms are now classified in: (i) open (or shared) shells, when $\rho_{\mathrm{BCP}}$ is small, $\nabla^{2} \rho_{\mathrm{BCP}} \sim 0, \mathrm{G}_{\mathrm{BCP}} / \rho_{\mathrm{BCP}}<1$, $\mathrm{H}_{\mathrm{BCP}} / \rho_{\mathrm{BCP}}<0$ and $\delta(\mathrm{A}, \mathrm{B})$ is the formal bond order (unless bond delocalization occurs); (ii) donor-acceptor, if $\rho_{\mathrm{BCP}}$ is small, $\nabla^{2} \rho_{\mathrm{BCP}}>0, \mathrm{G}_{\mathrm{BCP}} / \rho_{\mathrm{BCP}} \sim 1, \mathrm{H}_{\mathrm{BCP}} / \rho_{\mathrm{BCP}}<0$ and $\delta(\mathrm{A}, \mathrm{B})<$ 
formal bond order. In both cases $\int_{\mathrm{A} \cap \mathrm{B}} \rho$ has a medium/large value, despite $\rho$ being one order of magnitude lower than for covalent interactions between light atoms. When heavy atoms are involved the distinction between shared and donor-acceptor bonds is subtler than between corresponding light atom interactions [27].

On the basis of these considerations, to gain theoretical information on the bonding capabilities of compounds $\left[\mathrm{Zn}_{2} \mathrm{Cp}_{2}\right]$ (as model for $\left[\mathrm{Zn}_{2} \mathrm{Cp}^{*}{ }_{2}\right][1]$ ) and $\left[\mathrm{Zn}_{2} \mathrm{Ph}_{2}\right]$ (as model for $\mathrm{Zn}_{2} \mathrm{Ar}_{2}$ with $\mathrm{Ar}{ }^{\prime}=\mathrm{C}_{6} \mathrm{H}_{3}-2,6-\left(\mathrm{C}_{6} \mathrm{H}_{3}-2,6-i \mathrm{Pr}_{2}\right)_{2}$ [9]) towards several $\mathrm{ML}_{\mathrm{n}}$ metal fragments, a QTAIM study was undertaken. An analysis of the preservation of the $\mathrm{Zn}-\mathrm{Zn}$ interaction after coordination of the dizinc compound as a ligand was carried out. While our work was in progress, an experimental and theoretical study of the $\mathrm{Zn}-\mathrm{Zn}$ interactions in nickel and palladium complexes in which the dizinc unit act as a ligand was published [28].

\section{Computational details.}

Quantum chemical optimizations on the basis of the density functional theory (DFT) at the BP86 [29]/ Def2TZVPP [30] level of theory together with the D3(BJ) [31] correction by Grimme were carried out. Mo, W and Pd atoms were described with the LANL2DZ pseudopotential basis set [32]. The need for dispersion corrections has already been demonstrated by previous results on similar compounds [14]. The optimized geometries of all the compounds were characterized as energy minima either by non-existent imaginary frequencies $(\mathrm{NImag}=0)$, or by very low vibrational frequencies $\left(<20 \mathrm{~cm}^{-1}\right)$ in the diagonalization of the analytically computed Hessian (vibrational frequencies calculations). These very low vibrational frequencies that do not lead to energy minimum optimization have been reported in other cases, and seem to be associated to numerical errors in the DFT integration grid. They could be eliminated by much more expensive calculations with a better grid [33]. Electronic calculations were performed using Gaussian09 rev. D01 program [34] and topology parameters were studied within the framework QTAIM method as implemented in AIMALL program [35]. Cartesian coordinates of all optimized compounds are collected in the Supplementary Material (Table S1). 


\section{Results and Discussion}

\subsection{Some qualitative considerations on the Zn-Zn bond}

From an experimental point of view, the existence of a zinc-zinc bond is deduced from the $\mathrm{Zn}-\mathrm{Zn}$ distance obtained by X-ray crystallography. For this reason, a CSD search [36] of $\mathrm{X}$-ray characterized complexes containing $\mathrm{Zn}-\mathrm{Zn}$ bonds was carried out. Fig. 1 shows the resulting histogram, in which $\mathrm{Zn}-\mathrm{Zn}$ bond distances span the range 2.29-2.48 $\AA$, with a mean value of $2.38 \AA$. It can, therefore, be anticipated that $\mathrm{Zn}-\mathrm{Zn}$ lengths higher than $2.48 \AA$ would correspond to weak interactions. Additionally, with a zinc metallic radius of $1.34 \AA$, Zn- $\mathrm{Zn}$ distances larger than $2.68 \AA$ should denote very weak or negligible interactions. Besides these experimental considerations, the available theoretical tools will doubtless aid to define the features of weak $\mathrm{Zn}-\mathrm{Zn}$ interactions.

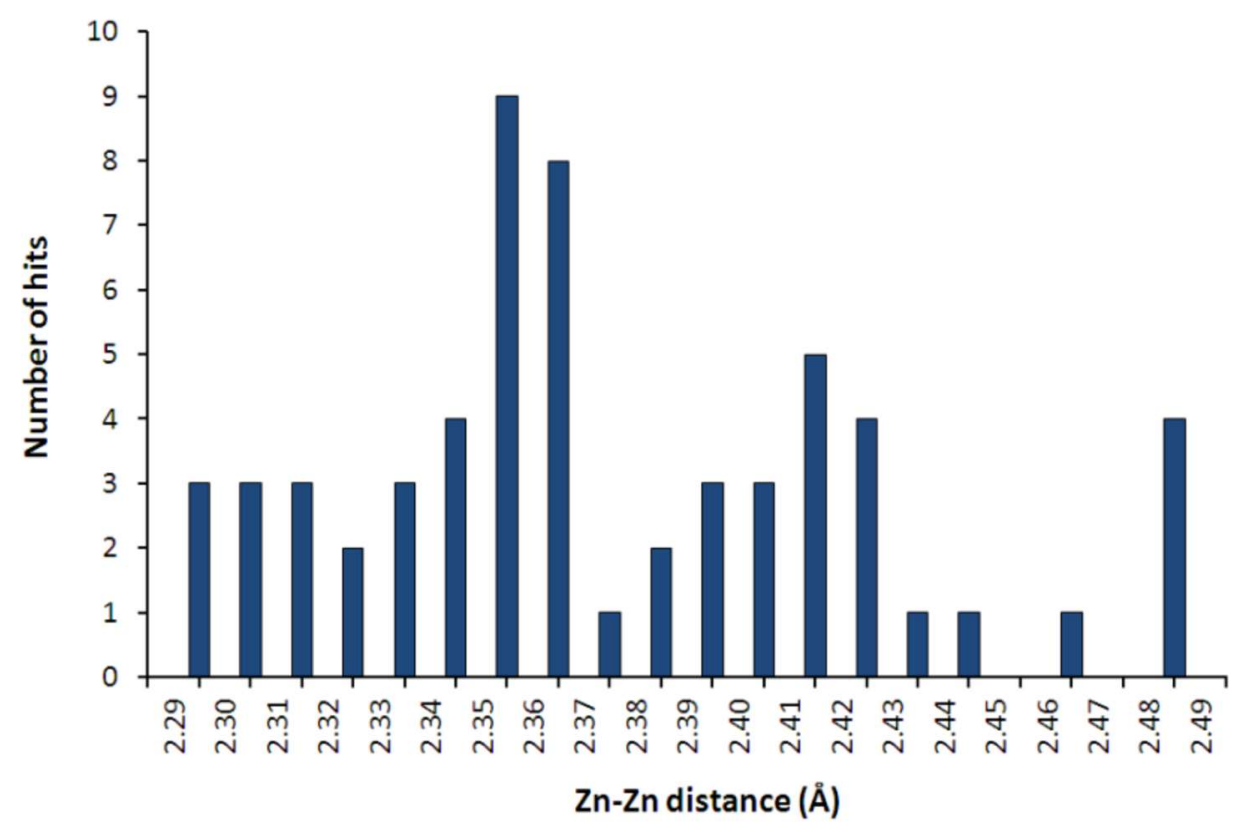

Fig. 1. Histogram of the $\mathrm{Zn}-\mathrm{Zn}$ distances found in structurally characterized dizinc complexes.

The existing knowledge on the nature of the $\mathrm{Zn}-\mathrm{Zn}$ bond [5-7] in these $\mathrm{d}^{10} \mathrm{~s}^{1}$ complexes allows for comparison of $\mathrm{CpZn}$ and $\mathrm{RZn}$ fragments with the $\mathrm{H}$ atom by means of the isolobal analogy [17]. Therefore, dizinc compounds would be isolobally related to the $\mathrm{H}_{2}$ molecule (Scheme 1) [28]. As dihydrogen can act as a $\sigma$-ligand in transition metal chemistry, we decided to explore theoretically the behaviour of $\left[\mathrm{Zn}_{2} \mathrm{Cp}_{2}\right]$ and $\left[\mathrm{Zn}_{2} \mathrm{Ph}_{2}\right]$ model compounds 
as $\eta^{2}-Z n_{2}$ ligands against some representative metal fragments, $M L_{n}$, and to analyze whether or not the $\mathrm{Zn}-\mathrm{Zn}$ interaction would be preserved on coordination (Scheme 2).

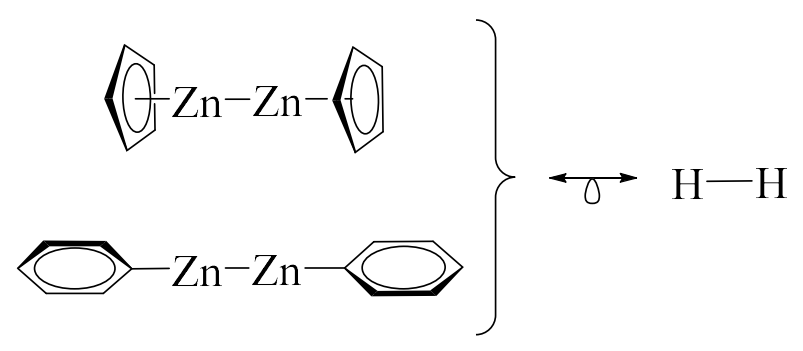

Scheme 1

The bonding scheme for the electronic interaction between a $\eta^{2}-Z n_{2}$ ligand and a transition metal (I in Scheme 2) is analogous to that well known for the dihydrogen ligand. For $\sigma$ bonding electron density would be transferred from the filled $\sigma$ molecular orbital (MO) of the dizinc compound (for instance, the HOMO-4 for $\left[\mathrm{Zn}_{2} \mathrm{Cp}_{2}\right]$ ), that features large contribution of the $\mathrm{Zn} s$ orbitals [5], to the metal (donation). A second interaction could involve the empty $\sigma^{*} \mathrm{MO}$ of the dizinc compound (the LUMO for $\left[\mathrm{Zn}_{2} \mathrm{Cp}_{2}\right]$, again with major contribution of $s$ orbitals), accepting by $\pi$ backbonding electron density from filled $\mathrm{M} d \pi$ orbitals. To accomplish this classical donation-backdonation scheme, the metal fragment must posses two electrons in MOs ( $\sigma$ and $\pi$ hybrid orbitals) topologically suited to maximize overlap. This qualitative fragment molecular orbital (FMO) description is illustrated in Scheme 3 for $\left[\mathrm{Zn}_{2} \mathrm{Cp}_{2}\right]$.
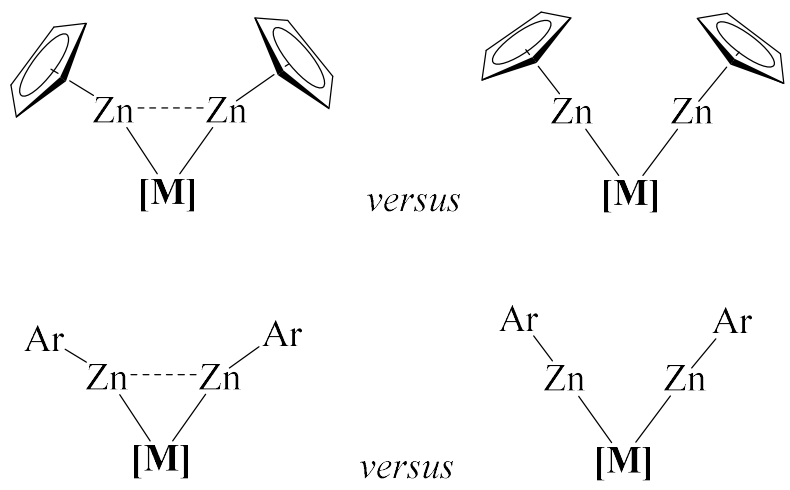

I

II

Scheme 2

Scheme 3 
On the basis of this description and in parallel to dihydrogen complexes, sufficiently strong backdonation would populate the $\sigma^{*} \mathrm{MO}$ of the dizinc compound triggering cleavage of the $\mathrm{Zn}-\mathrm{Zn}$ bond (II in Scheme 2). The corresponding M-Zn-Cp or M-Zn-Ar moieties in II are characterized by approximately linear $\mathrm{M}-\mathrm{Zn}-\mathrm{C}_{\mathrm{t}}\left(\mathrm{C}_{\mathrm{t}}=\right.$ centroid of $\left.\mathrm{Cp}\right)$ and $\mathrm{M}-\mathrm{Zn}-\mathrm{C}$ bond angles [17-19]. By contrast, the $\eta^{2}-Z n_{2}$ coordination of $\left[\mathrm{Zn}_{2} \mathrm{Cp}_{2}\right]$ or $\left[\mathrm{Zn}_{2} \mathrm{Ph}_{2}\right]$ to a metal centre in I entails a concomitant bending of the $\mathrm{Zn}-\mathrm{Zn}-\mathrm{C}_{\mathrm{t}}$ or $\mathrm{Zn}-\mathrm{Zn}-\mathrm{C}$ bond angles, respectively, from the original $c a .180^{\circ}$ value. While our work was in progress, Fisher, Frenking and coworkers reported three examples that fit well with situation I. Thus, they studied $\left[\mathrm{Zn}_{3} \mathrm{Cp}_{3}\right]^{+}$and $\left[\mathrm{Zn}_{2} \mathrm{CuCp}_{3}\right]$ complexes [37], which show bending angles around $150^{\circ}$ and $\mathrm{Zn}-\mathrm{Zn}$ bond lengths of 2.430(1) (average) and 2.357(1) A, respectively, besides complex $\left[\left(\mathrm{Zn}_{2} \mathrm{Cp} * \mathrm{Me}\right) \mathrm{Ni}\left(\mathrm{PMe}_{3}\right)_{3}\right][28]$, characterized by a $\mathrm{Zn}-\mathrm{Zn}$ distance of 2.525(1) $\AA$ and a $\mathrm{Zn}-\mathrm{Zn}$ $\mathrm{C}_{t}$ angle of $118.76^{\circ}$. Although detailed theoretical calculations for these complexes were provided by these authors [28,37], a qualitative FMO description of the bonding scheme can be easily presented, assuming that the existence of the $\eta^{2}-Z n_{2}$ ligand is compatible with the found $\mathrm{Zn}-\mathrm{Zn}$ distances. The electronic portrayal implies the interaction of the $\mathrm{d}^{10}-\mathrm{MCp}$ fragment $\left(\mathrm{ZnCp}^{*+}\right.$ and $\left.\mathrm{CuCp} *\right)$, or the isolobal $\mathrm{d}^{10}-\mathrm{ML}_{3}$ one $\left(\mathrm{Ni}\left(\mathrm{PMe}_{3}\right)_{3}\right)$, with the $\eta^{2}-\mathrm{Zn}_{2}$ ligand (see Scheme S1 in the Supplementary Material). This interpretation was previously proposed by Fisher, Frenking and coworkers with alternative formulations for these complexes of type $\left[\left(\eta^{2}-\mathrm{Zn}_{2} \mathrm{Cp}^{*}{ }_{2}\right) \mathrm{ML}_{\mathrm{n}}\right][28,37]$.

To gain information about the effect of the bending on the $\sigma$ and $\sigma^{*}$ frontier orbitals, single point calculations were carried out with $\left[\mathrm{Zn}_{2} \mathrm{Cp}_{2}\right]$ and $\left[\mathrm{Zn}_{2} \mathrm{Ph}_{2}\right]$ complexes at fixed $\mathrm{Zn}-\mathrm{Zn}-\mathrm{C}_{\mathrm{t}}$ and $\mathrm{Zn}-\mathrm{Zn}-\mathrm{C}$ bond angles, respectively, of $170^{\circ}, 160^{\circ}$ and $150^{\circ}$. Fig. 2 shows the energy variation found for the $\sigma$ and $\sigma^{*}$ MOs of $\left[\mathrm{Zn}_{2} \mathrm{Cp}_{2}\right]$. Bending of the dizincocene implies a very small stabilization of the $\sigma \mathrm{MO}(\mathrm{HOMO}-4)$ and a higher energy stabilization of the antibonding $\sigma^{*}$ MO. The distortion improves the $\pi$-acidity of $\sigma^{*}$ MOs thus favoring the interaction of the $\eta^{2}-Z n_{2}-\left[\mathrm{Zn}_{2} \mathrm{Cp}_{2}\right]$ ligand with the metal. For the related bis(aryl) dizinc complex $\left[\mathrm{Zn}_{2} \mathrm{Ph}_{2}\right]$, a slight energy variation of the $\sigma \mathrm{MO}(\mathrm{HOMO})$ is computed upon bending and there is also a major stabilization of the antibonding $\sigma^{*}$ MO (Fig. 3). This stabilization is higher than that observed for $\left[\mathrm{Zn}_{2} \mathrm{Cp}_{2}\right]$ and, in contrast with the latter, the precise constitution of $\sigma^{*}$ MO changes with bending. At $160^{\circ}$ there are two MOs with antibonding $\sigma^{*}$ character (LUMO+2 and LUMO+5), so that the corresponding point in Fig. 3 is an energy average of the two MOs. These $\sigma^{*}$ orbitals, one with mainly $s$ character, the other with large $p$ contribution can be found in Fig. S1 (Supplementary Material). The bending induces 
hybridization of the $\sigma^{*} \mathrm{MO}$, with an increase of the $p$ character which affords well suited topology for the backdonation interaction (Fig. 3). The higher energy stabilization of the antibonding $\sigma^{*} \mathrm{MO}$ observed for $\left[\mathrm{Zn}_{2} \mathrm{Ph}_{2}\right]$ would predict a better $\pi$-acceptor behaviour of $\left[\mathrm{Zn}_{2} \mathrm{Ph}_{2}\right]$ as ligand than that expected for $\left[\mathrm{Zn}_{2} \mathrm{Cp}_{2}\right]$. Additionally, the higher $\sigma \mathrm{MO}$ energy of $\left[\mathrm{Zn}_{2} \mathrm{Ph}_{2}\right]$ would anticipate a better donor behaviour of this complex as ligand than that of $\left[\mathrm{Zn}_{2} \mathrm{Cp}_{2}\right]$.

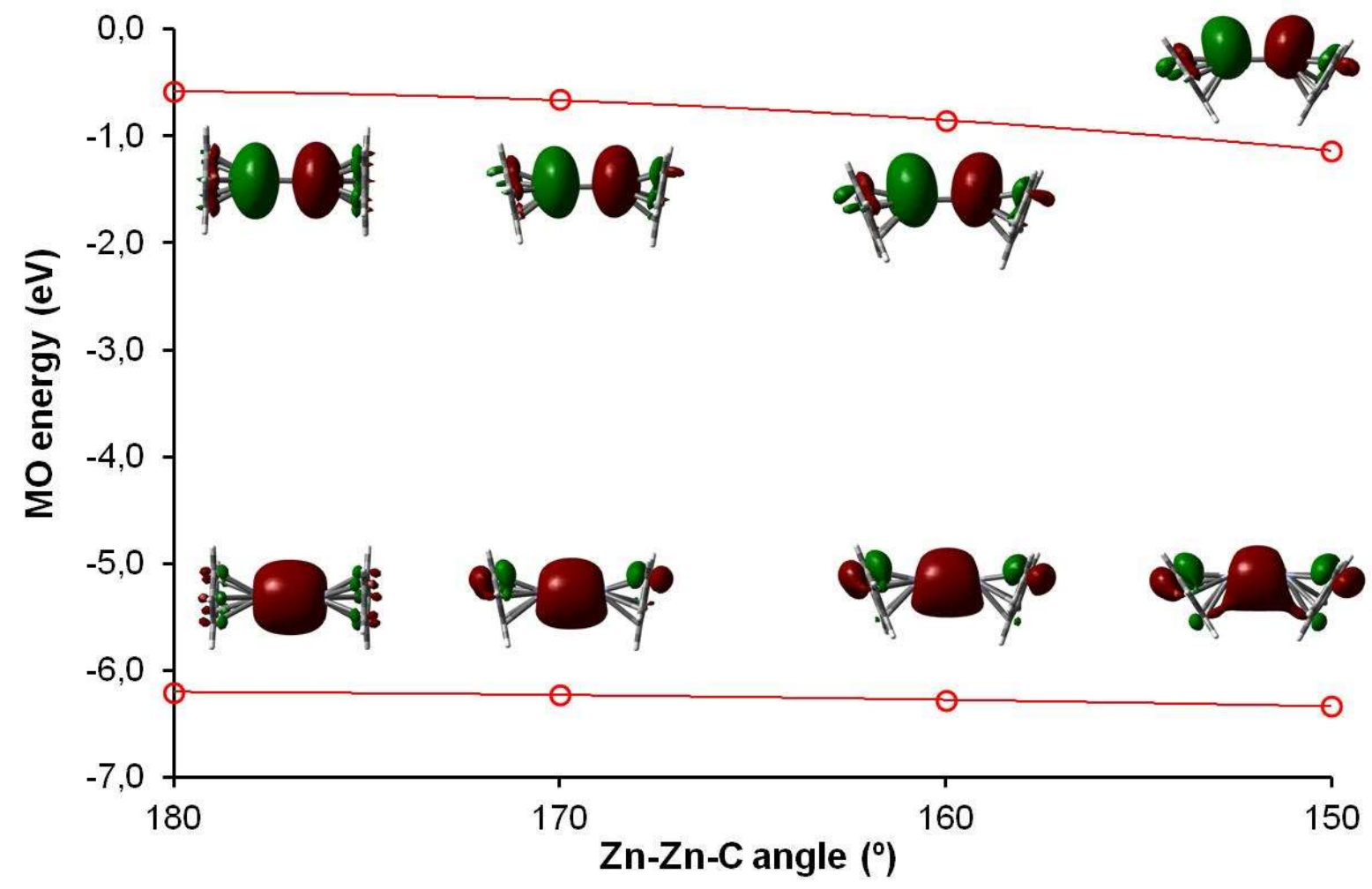

Fig. 2. Energy variation of the $\sigma$ and $\sigma^{*}$ MOs of complex $\left[\mathrm{Zn}_{2} \mathrm{Cp}_{2}\right]$, upon bending of the $\mathrm{Zn}-\mathrm{Zn}-\mathrm{C}_{\mathrm{t}}$ angles (Isovalue of 0.04 for the MO drawings). 


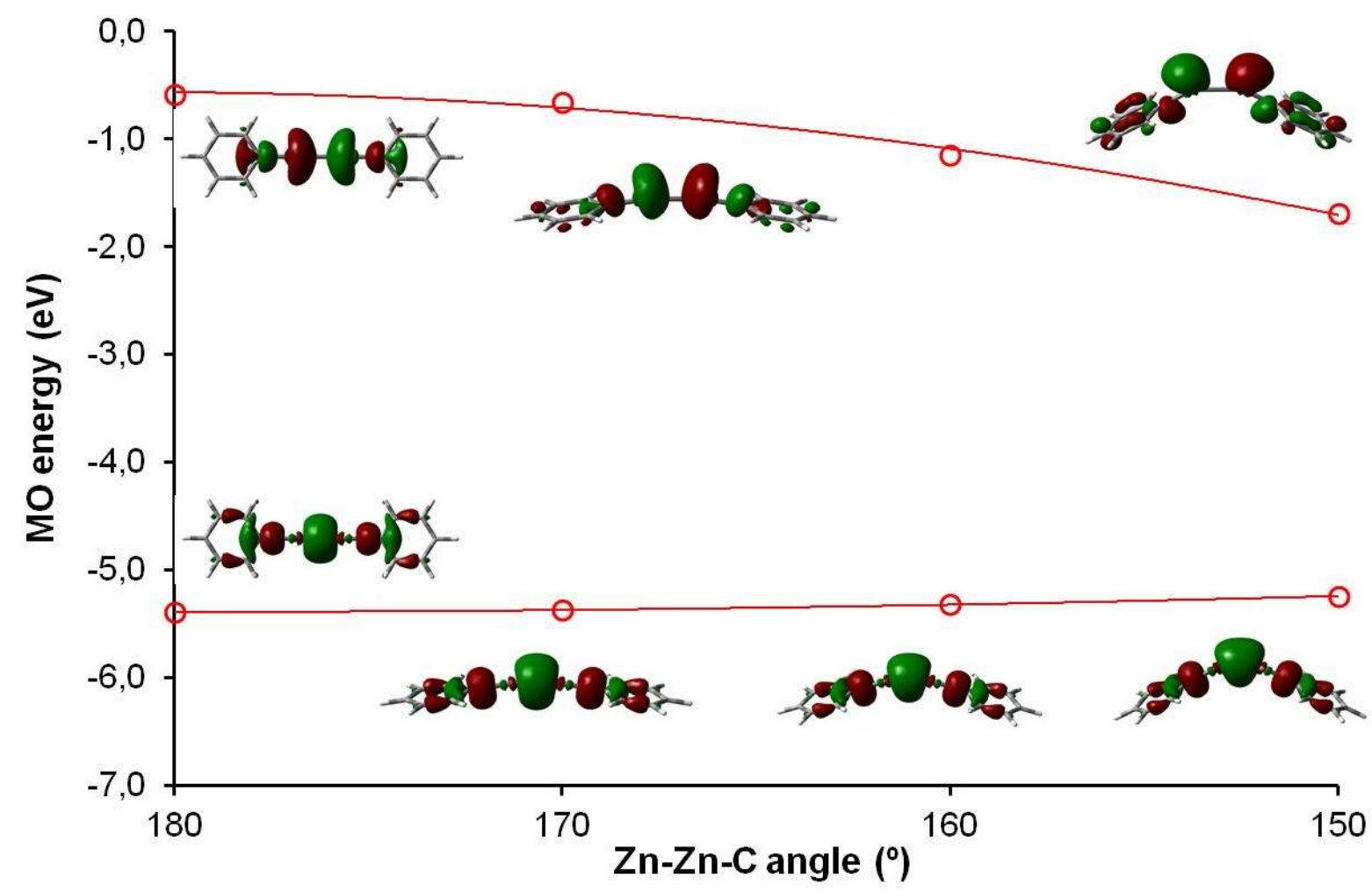

Fig. 3. Energy variation of the $\sigma$ and $\sigma^{*}$ MOs of complex $\left[\mathrm{Zn}_{2} \mathrm{Ph}_{2}\right]$, upon bending of the $\mathrm{Zn}-\mathrm{Zn}-\mathrm{C}$ angles (Isovalue of 0.04 for the MO drawings). For details about the $\sigma^{*} \mathrm{MOs}$ at $160^{\circ}$ see Supplementary Material (Fig. S1). 


\subsection{QTAIM analysis of the $\mathrm{Zn}-\mathrm{Zn}$ bond}

With these precedents, we have theoretically analyzed the coordination of the model $\eta^{2}-Z_{2}$ ligands $\left[\mathrm{Zn}_{2} \mathrm{Cp}_{2}\right]$ and $\left[\mathrm{Zn}_{2} \mathrm{Ph}_{2}\right]$ to selected $\mathrm{d}^{8}-\mathrm{ML}_{4}, \mathrm{~d}^{6}-\mathrm{ML}_{5}$, and $\mathrm{d}^{10}-\mathrm{ML}_{2}$ metal fragments. In all cases, the fragment frontier MOs are an empty $\sigma$ hybrid and a filled $\pi$ hybrid orbitals, topologically matched for the $\sigma$-bonding/ $\pi$-backbonding interactions with the $\eta^{2}-Z n_{2}$ ligand, as sketched in Scheme 3. Model complexes [( $\left.\mathrm{ZnR})_{2} \mathrm{Fe}(\mathrm{CO})_{4}\right],\left[\left(\eta^{2}-\mathrm{Zn}_{2} \mathrm{R}_{2}\right) \mathrm{M}(\mathrm{CO})_{5}\right]$ and $\left[\left(\eta^{2}-\mathrm{Zn}_{2} \mathrm{R}_{2}\right) \mathrm{Pd}\left(\mathrm{PR}^{\prime}\right)_{2}\right)_{2}\left(\mathrm{R}=\mathrm{Cp}, \mathrm{Ph} ; \mathrm{M}=\mathrm{Cr}, \mathrm{Mo}, \mathrm{W} ; \mathrm{R}^{\prime}=\mathrm{F}, \mathrm{H}, \mathrm{Me}\right)$ were optimized without symmetry restrictions. For comparative purposes the dizinc model compounds $\left[\mathrm{Zn}_{2} \mathrm{Cp}_{2}\right]$ and $\left[\mathrm{Zn}_{2} \mathrm{Ph}_{2}\right]$ were also computed. Our results for $\left[\mathrm{Zn}_{2} \mathrm{Cp}_{2}\right]$ are in agreement with those already in the bibliography [2,3a,5]. Figs. 4 and 5 show the resulting optimized structures, while selected structural data for these complexes are collected in Table S2. Values of topological properties for selected bonds can be found in Table 1. Topological graphs showing bond paths (BPs) and critical points (CPs) are collected in Fig. S2 (Supplementary Material).

As can be seen in Table 1 , the values of $\rho_{\mathrm{BCP}}, \nabla^{2} \rho_{\mathrm{BCP}}$ and $\delta(\mathrm{Zn}, \mathrm{Zn})$ delocalization indexes for all $\left[\left(\mathrm{Zn}_{2} \mathrm{Cp}_{2}\right) \mathrm{ML}_{\mathrm{n}}\right]$ and $\left[\left(\mathrm{Zn}_{2} \mathrm{Ph}_{2}\right) \mathrm{ML}_{\mathrm{n}}\right]$ complexes are lower than in the parent dizinc compounds $\left[\mathrm{Zn}_{2} \mathrm{Cp}_{2}\right]$ and $\left[\mathrm{Zn}_{2} \mathrm{Ph}_{2}\right]$, respectively, evidencing the weakening of the $\mathrm{Zn}-\mathrm{Zn}$ bond upon coordination to $\mathrm{ML}_{\mathrm{n}}$ fragments, which is expected in accordance to the donation/backdonation scheme previously outlined. Concerning $\mathrm{M}-\mathrm{Zn}$ interactions, $\mathrm{M}-\mathrm{Zn}$ bonds were clearly found with BCP located at roughly the midpoints of the M-Zn vectors. Calculated parameters $\rho_{\mathrm{BCP}}$ and $\nabla^{2} \rho_{\mathrm{BCP}}$ are small and positive, as expected for heavy atom interactions, whereas the positive, smaller than unity values obtained for $G_{B C P} / \rho_{B C P}$ ratios imply the presence of open-shell M-Zn interactions. This is also supported by the values of the $\left|V_{B C P}\right| / G_{B C P}$ ratio found in the transient region. The negative, albeit small values of the $B D$ parameter can be taken as indicative of covalency of the bond, although the degree must not be very high. The $\delta(\mathrm{M}, \mathrm{Zn})$ delocalization index alludes to the number of electron pairs shared between the $\mathrm{M}$ and $\mathrm{Zn}$ atoms. It is in the range 0.367-0.729, suggesting the presence of polar rather than pure covalent bonds. Although the $\rho_{\mathrm{BC}}$ value is not a decisive factor in predicting the nature of the bond when heavy atoms are present, it always follows the same trend in our calculations, viz. $\rho$ at M-Zn BPC is larger for $\mathrm{Zn}_{2} \mathrm{Ph}_{2}$ fragments than for $\mathrm{Zn}_{2} \mathrm{Cp}_{2}$ analogues. Likewise, $\mathrm{G}_{\mathrm{BCP}} / \rho_{\mathrm{BCP}}$ and $\mathrm{H}_{\mathrm{BCP}} / \rho_{\mathrm{BCP}}$ ratios are lower than expected for pure covalent bonds between non metal atoms [26]. 

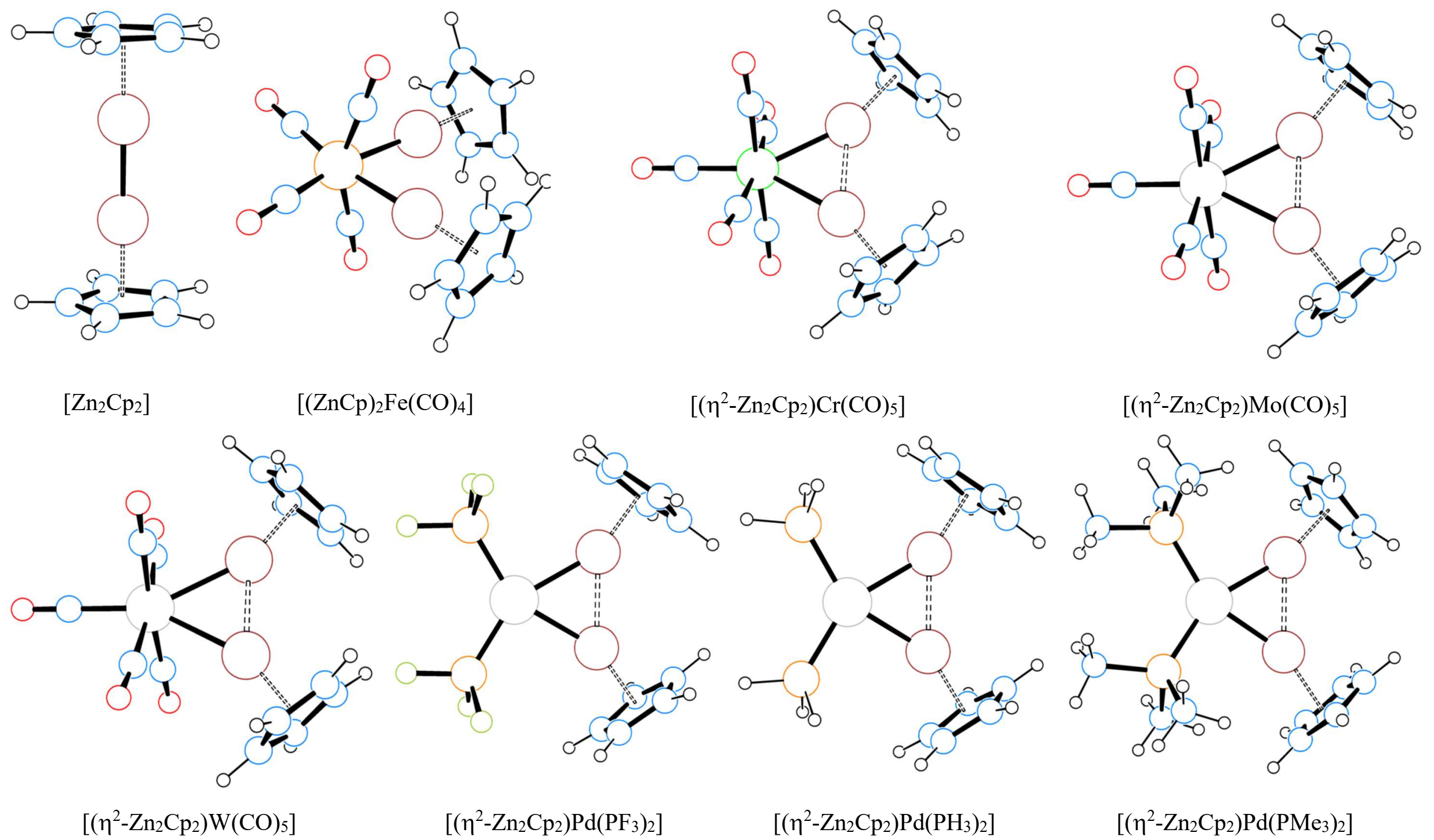

Fig. 4. Optimized structures for model complexes $\left[\left(\mathrm{Zn}_{2} \mathrm{Cp}_{2}\right) \mathrm{ML}_{n}\right]$. 


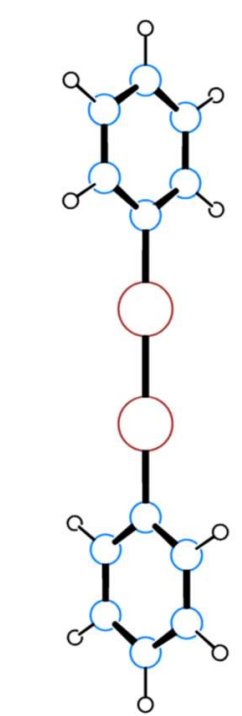

$\left[\mathrm{Zn}_{2} \mathrm{Ph}_{2}\right]$

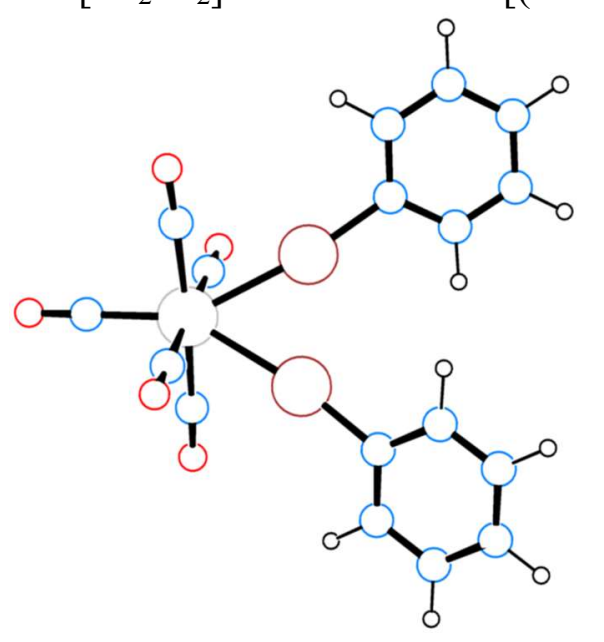

$\left[(\mathrm{ZnCp})_{2} \mathrm{~W}(\mathrm{CO})_{5}\right]$

Fig. 5. Optimized structur

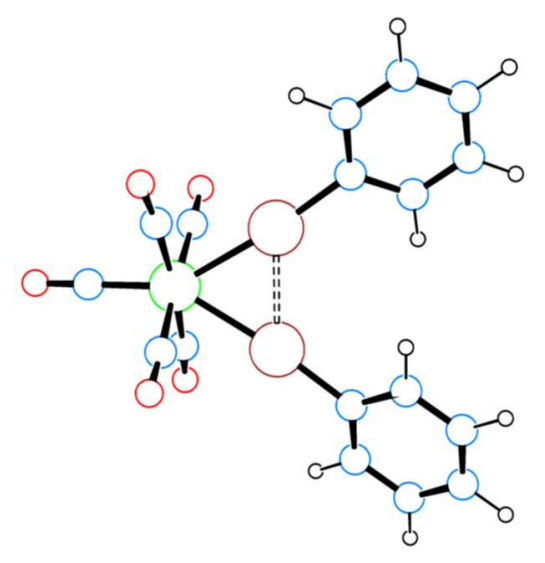

$\left[\left(\eta^{2}-\mathrm{Zn}_{2} \mathrm{Ph}_{2}\right) \mathrm{Cr}(\mathrm{CO})_{5}\right]$

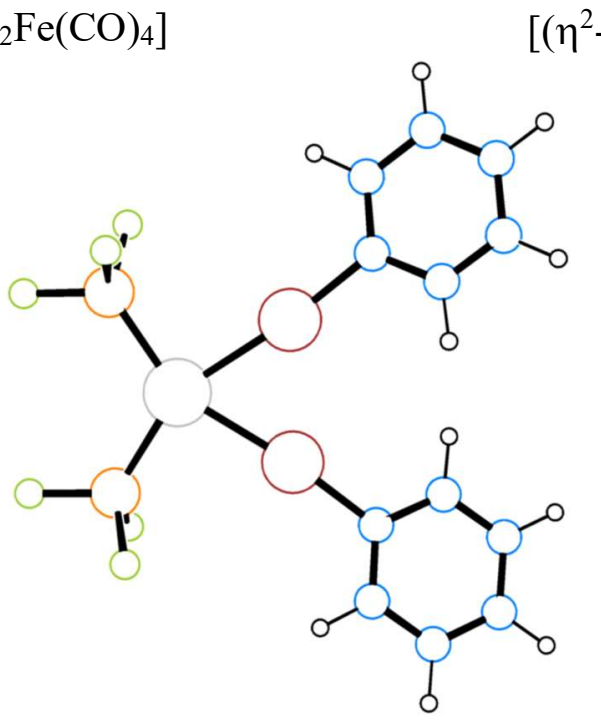

$\left[(\mathrm{ZnPh})_{2} \mathrm{Pd}\left(\mathrm{PF}_{3}\right)_{2}\right]$

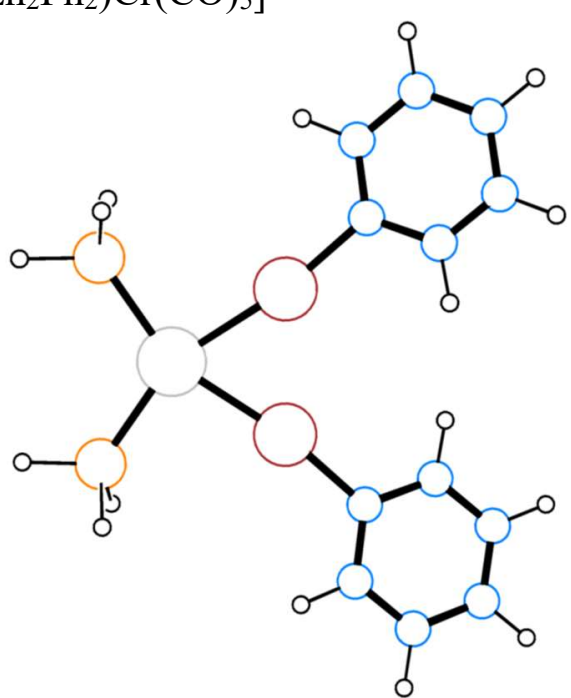

$\left[(\mathrm{ZnPh})_{2} \mathrm{Pd}\left(\mathrm{PH}_{3}\right)_{2}\right]$

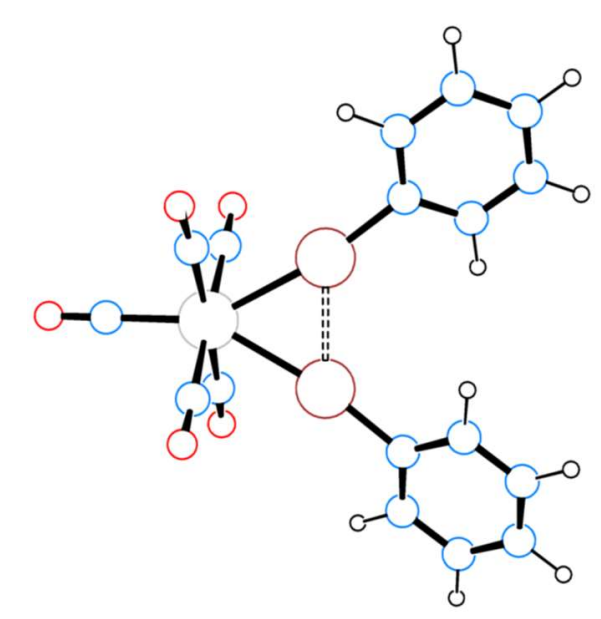

$\left[\left(\eta^{2}-\mathrm{Zn}_{2} \mathrm{Ph}_{2}\right) \mathrm{Mo}(\mathrm{CO})_{5}\right]$

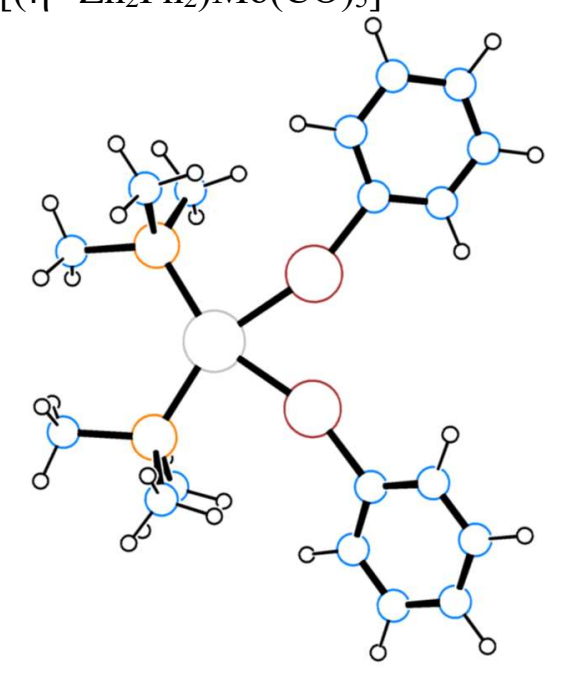

$\left[(\mathrm{ZnPh})_{2} \mathrm{Pd}\left(\mathrm{PMe}_{3}\right)_{2}\right]$ 
Table 1. Topological properties for selected bonds of $\left[(\mathrm{ZnR})_{2} \mathrm{Fe}(\mathrm{CO})_{4}\right],\left[\left(\eta^{2}-\mathrm{Zn}_{2} \mathrm{R}_{2}\right) \mathrm{M}(\mathrm{CO})_{5}\right]$ and $\left[\left(\eta^{2}-\mathrm{Zn}_{2} \mathrm{R}_{2}\right) \mathrm{Pd}\left(\mathrm{PR}{ }_{3}\right)_{2}\right](\mathrm{R}=\mathrm{Cp}, \mathrm{Ph} ; \mathrm{M}=\mathrm{Cr}$, Mo, W; R' = F, H, Me) complexes. ${ }^{\text {a }}$

\begin{tabular}{|c|c|c|c|c|c|c|c|c|c|c|c|}
\hline Complex & A-B & Distance & ОВСР & $\nabla^{2} \rho \mathrm{BCP}$ & $\delta(\mathrm{A}, \mathrm{B})$ & $\varepsilon_{\mathrm{BCP}}$ & $\left|\mathbf{V}_{\text {BCP }}\right| / \mathbf{G B C P}_{\text {BC }}$ & 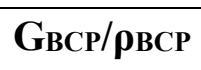 & 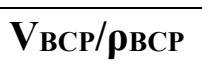 & НВСР/ $/$ ВСР & $\int_{M \cap Z n \rho}$ \\
\hline$\left[\mathrm{Zn}_{2} \mathrm{Cp}_{2}\right]$ & $\mathrm{Zn}-\mathrm{Zn}$ & 2.303 & 0.065 & 0.069 & 0.960 & 0.000 & 1.530 & 0.564 & -0.863 & -0.299 & 0.701 \\
\hline$\left[\mathrm{Zn}_{2} \mathrm{Ph}_{2}\right]$ & $\mathrm{Zn}-\mathrm{Zn}$ & 2.403 & 0.062 & 0.019 & 0.882 & 0.000 & 1.805 & 0.398 & -0.718 & -0.320 & 0.644 \\
\hline$\left[(\mathrm{ZnCp})_{2} \mathrm{Fe}(\mathrm{CO})_{4}\right]$ & $\mathrm{Zn} \cdots \mathrm{Zn}$ & 2.945 & & & $(0.120)$ & & & & & & \\
\hline \multirow{2}{*}[(\mathrm{ZnPh})_{2}\mathrm{Fe}(\mathrm{CO})_{4}]{} & $\mathrm{Fe}-\mathrm{Zn}$ & 2.372 & 0.059 & 0.072 & 0.543 & 0.140 & 1.488 & 0.591 & -0.879 & -0.288 & 0.883 \\
\hline & $\mathrm{Zn} \cdots \mathrm{Zn}$ & 3.187 & & & $(0.075)$ & & & & & & \\
\hline$\left[\left(\eta^{2}-\mathrm{Zn}_{2} \mathrm{Cp}_{2}\right) \mathrm{Cr}(\mathrm{CO})_{5}\right]$ & $\mathrm{Zn}-\mathrm{Cr}-\mathrm{Zn}$ & & 0.039 & 0.035 & & & & & & & \\
\hline \multirow{3}{*}[(\eta^{2}-\mathrm{Zn}_{2}\mathrm{Ph}_{2})\mathrm{Cr}(\mathrm{CO})_{5}]{} & $\mathrm{Cr}-\mathrm{Zn}$ & 2.516 & 0.048 & 0.042 & 0.407 & 0.232 & 1.588 & 0.524 & -0.832 & -0.308 & 0.725 \\
\hline & $\mathrm{Zn}-\mathrm{Zn}$ & 2.556 & 0.044 & 0.015 & 0.360 & 1.146 & 1.775 & 0.378 & -0.671 & -0.293 & \\
\hline & $\mathrm{Zn}-\mathrm{Cr}-\mathrm{Zn}$ & & 0.042 & 0.014 & & & & & & & \\
\hline $\begin{array}{l}{\left[\left(\eta^{2}-\right.\right.} \\
\left.\left.\mathrm{Zn}_{2} \mathrm{Cp}_{2}\right) \mathrm{Mo}(\mathrm{CO})_{5}\right]\end{array}$ & Mo-Zn & 2.677 & 0.044 & 0.044 & 0.405 & 0.176 & 1.519 & 0.520 & -0.790 & -0.270 & 0.668 \\
\hline \multirow{2}{*}{$\begin{array}{l}{\left[\left(\eta^{2}-\right.\right.} \\
\left.\left.\mathrm{Zn}_{2} \mathrm{Ph}_{2}\right) \mathrm{Mo}(\mathrm{CO})_{5}\right]\end{array}$} & $\mathrm{Zn}-\mathrm{Zn}$ & 2.570 & 0.044 & 0.015 & 0.393 & 0.987 & 1.803 & 0.359 & -0.647 & -0.288 & \\
\hline & Zn-Mo-Zn & & 0.042 & 0.019 & & & & & & & \\
\hline \multirow{3}{*}[(\eta^{2}-\mathrm{Zn}_{2}\mathrm{Cp}_{2})\mathrm{W}(\mathrm{CO})_{5}]{} & $\mathrm{W}-\mathrm{Zn}$ & 2.673 & 0.064 & 0.087 & 0.522 & 0.222 & 1.463 & 0.441 & -0.645 & -0.204 & 0.858 \\
\hline & $\mathrm{Zn}-\mathrm{Zn}$ & 2.462 & 0.053 & 0.032 & 0.413 & 1.302 & 1.677 & 0.414 & -0.694 & -0.280 & \\
\hline & Zn-W-Zn & & 0.044 & 0.021 & & & & & & & \\
\hline \multirow{2}{*}[(\mathrm{ZnPh})_{2}\mathrm{W}(\mathrm{CO})_{5}]{} & $\mathrm{W}-\mathrm{Zn}$ & 2.649 & 0.068 & 0.089 & 0.565 & 0.179 & 1.492 & 0.447 & -0.668 & -0.220 & 1.150 \\
\hline & $\mathrm{Zn} \cdots \mathrm{Zn}$ & 2.573 & & & $(0.304)$ & & & & & & \\
\hline
\end{tabular}




\begin{tabular}{|c|c|c|c|c|c|c|c|c|c|c|c|}
\hline \multirow{3}{*}[(\eta^{2}-\mathrm{Zn}_{2}\mathrm{Cp}_{2})\mathrm{Pd}(\mathrm{PF}_{3})_{2}]{} & $\mathrm{Pd}-\mathrm{Zn}$ & 2.508 & 0.055 & 0.096 & 0.601 & 0.264 & 1.348 & 0.672 & -0.907 & -0.234 & 0.595 \\
\hline & $\mathrm{Zn}-\mathrm{Zn}$ & 2.488 & 0.050 & 0.028 & 0.491 & 0.414 & 1.671 & 0.436 & -0.729 & -0.293 & \\
\hline & Zn-Pd-Zn & & 0.046 & 0.040 & & & & & & & \\
\hline$\left[(\mathrm{ZnPh})_{2} \mathrm{Pd}\left(\mathrm{PF}_{3}\right)_{2}\right]$ & $\mathrm{Pd}-\mathrm{Zn}$ & 2.495 & 0.058 & 0.088 & 0.674 & 0.214 & 1.405 & 0.628 & -0.882 & -0.254 & 0.905 \\
\hline \multirow{2}{*}{$\begin{array}{l}{\left[\left(\eta^{2}-\right.\right.} \\
\left.\left.\mathrm{Zn}{ }_{2} \mathrm{Cp}_{2}\right) \mathrm{Pd}\left(\mathrm{PH}_{3}\right)_{2}\right]\end{array}$} & $\mathrm{Pd}-\mathrm{Zn}$ & 2.478 & 0.057 & 0.104 & 0.651 & 0.174 & 1.346 & 0.704 & -0.948 & -0.244 & 0.646 \\
\hline & $\mathrm{Zn}-\mathrm{Zn}$ & 2.522 & 0.048 & 0.025 & 0.475 & 0.466 & 1.686 & 0.422 & -0.711 & -0.290 & \\
\hline$\left[(\mathrm{ZnPh})_{2} \mathrm{Pd}\left(\mathrm{PH}_{3}\right)_{2}\right]$ & $\mathrm{Zn} \cdots \mathrm{Zn}$ & 2.690 & & & $(0.354)$ & & & & & & \\
\hline \multirow{3}{*}{$\begin{array}{l}{\left[\left(\eta^{2}-\right.\right.} \\
\left.\left.\mathrm{Zn}_{2} \mathrm{Cp}_{2}\right) \mathrm{Pd}\left(\mathrm{PMe}_{3}\right)_{2}\right]\end{array}$} & $\mathrm{Pd}-\mathrm{Zn}$ & 2.460 & 0.060 & 0.107 & 0.699 & 0.140 & 1.364 & 0.705 & -0.962 & -0.257 & 0.648 \\
\hline & $\mathrm{Zn}-\mathrm{Zn}$ & 2.583 & 0.044 & 0.021 & 0.412 & 0.796 & 1.699 & 0.399 & -0.679 & -0.279 & \\
\hline & Zn-Pd-Zn & & 0.043 & 0.036 & & & & & & & \\
\hline$\left[(\mathrm{ZnPh})_{2} \mathrm{Pd}\left(\mathrm{PMe}_{3}\right)_{2}\right]$ & $\mathrm{Pd}-\mathrm{Zn}$ & 2.450 & 0.062 & 0.106 & 0.726 & 0.140 & 1.380 & 0.696 & -0.961 & -0.265 & 0.988 \\
\hline
\end{tabular}

${ }^{a}$ All dimensioned quantities are in atomic units (a.u.) except distances which are in Angstroms ( $\AA$ ). The subscript BCP implies that the value is reported at the bond critical point. A-B and $\mathrm{A} \cdots \mathrm{B}$ denote bonded and non bonded distances according to the QTAIM analysis. $\delta(A, B)$ denotes the delocalization index between atoms $\mathrm{A}$ and $\mathrm{B}$, values in parenthesis imply non bonded atoms. $\varepsilon_{\mathrm{BCP}}$ denotes ellipticity at the $\mathrm{BCP}$. $\mid \mathrm{V}_{\mathrm{BCP}} / \mathrm{G}_{\mathrm{BCP}}$ is an adimensional ratio (see text). $\mathrm{G}_{\mathrm{BCP}} / \rho_{\mathrm{BCP}}, \mathrm{V}_{\mathrm{BCP}} / \rho_{\mathrm{BCP}}$ and $\mathrm{H}_{\mathrm{BCP}} / \rho_{\mathrm{BCP}}$ are the potential, kinetic and total energy ratios at the $\mathrm{BCP}$, respectively. $\int_{\mathrm{M} \cap \mathrm{Zn}} \rho$ accounts for the integrated electron density over the whole M-Zn interatomic surface. Zn-M-Zn corresponds to RCPs. 
Table 1 shows that $\mathrm{Zn}-\mathrm{Zn}$ bonds are not preserved after $\mathrm{ML}_{\mathrm{n}}$ coordination in all the complexes under study. Only those with a $\mathrm{Zn}-\mathrm{Zn}$ distance smaller than $2.583 \AA$ present a bond path ( $\mathrm{Zn}-\mathrm{Zn}$ range: $2.447-2.583 \AA$ ). This is also in agreement with the qualitative prediction previously proposed. A more detailed analysis indicates that the absence of a $\mathrm{Zn}$ $\mathrm{Zn}$ bond for the iron $\left[(\mathrm{ZnR})_{2} \mathrm{Fe}(\mathrm{CO})_{4}\right](\mathrm{R}=\mathrm{Cp}, \mathrm{Ph})$ complexes, that feature calculated $\mathrm{Zn} \cdots \mathrm{Zn}$ separations close to $3 \AA$. The Fe-Zn- $\mathrm{C}_{\mathrm{t}}$ and Fe-Zn-C angles are close to $180^{\circ}$ (Table $\mathrm{S} 1)$ and the $\mathrm{Fe}-\mathrm{Zn}$ distance is similar to those found in related X-ray characterized complexes [38]. The $\mathrm{Zn}-\mathrm{Zn}$ bond is however preserved for the $\mathrm{Cr}$ and Mo interacting $\left[\mathrm{M}(\mathrm{CO})_{5}\right]$ fragments. In these cases, $\delta(\mathrm{Zn}, \mathrm{Zn})$ and $\delta(\mathrm{M}, \mathrm{Zn})(\mathrm{M}=\mathrm{Cr}$, Mo) delocalization indexes are larger and smaller, respectively, for the $\left[\left(\eta^{2}-\mathrm{Zn}_{2} \mathrm{Cp}_{2}\right) \mathrm{M}(\mathrm{CO})_{5}\right](\mathrm{M}=\mathrm{Cr}$, Mo) structures than for the $\left[\left(\eta^{2}-\mathrm{Zn}_{2} \mathrm{Ph}_{2}\right) \mathrm{M}(\mathrm{CO})_{5}\right](\mathrm{M}=\mathrm{Cr}, \mathrm{Mo})$ analogues, indicating that the higher $\mathrm{Zn}-\mathrm{Zn}$ bond order, the more reduced electron sharing between the metal and zinc atoms becomes. The computed $\mathrm{Cr}-\mathrm{Zn}$ and Mo-Zn distances are in agreement with the experimental values found for complexes containing Cr-Zn [39] and Mo-Zn [39,40] bonds. Moving down the group in the Periodic Table to consider the $\left[\mathrm{W}(\mathrm{CO})_{5}\right]$ fragment reveals that the $\mathrm{Zn}-\mathrm{Zn}$ bond is only present for the cyclopentadienyl complex $\left[\left(\eta^{2}-\mathrm{Zn}_{2} \mathrm{Cp} \mathrm{p}_{2}\right) \mathrm{W}(\mathrm{CO})_{5}\right]$. Although this result may be surprising bearing in mind the similar $\mathrm{Mo}(\mathrm{W})-\mathrm{Zn}$ and $\mathrm{Zn}-\mathrm{Zn}$ distances calculated for the molybdenum and tungsten complexes $\left[\left(\mathrm{Zn}_{2} \mathrm{R}_{2}\right) \mathrm{M}(\mathrm{CO})_{5}\right]$, it can be understood in terms of the larger M-L overlap expected for the tungsten fragment that would increase backdonation to the $\mathrm{Zn}-\mathrm{Zn}$ bond ultimately abating the $\mathrm{Zn}-\mathrm{Zn}$ interaction. To estimate the metal-to-CO $\pi$-backdonation in these $\left[(\mathrm{ZnR})_{2} \mathrm{M}(\mathrm{CO})_{\mathrm{n}}\right]$ complexes, we have calculated the $\delta\left(\mathrm{M}, \mathrm{O}_{\mathrm{CO}}\right)$ delocalization index, as it involves significant $\mathrm{M} \cdots \mathrm{O}_{\mathrm{CO}}$ interaction [26]. In fact, the values of $\delta\left(\mathrm{M}, \mathrm{O}_{\mathrm{CO}}\right)$ when there is no $\pi$-backdonation are very low $(<0.1)$, while those found in complexes with important backdonation are much larger, ranging from 0.15 to 0.25 [22b,26,41]. Average $\delta\left(\mathrm{M}, \mathrm{O}_{\mathrm{CO}}\right)$ delocalization indexes for the carbonyl computed derivatives are collected in Table 2. Their magnitude evidences significant backdonation in all cases, in the order $\mathrm{Fe}(\mathrm{CO})_{4}>\mathrm{W}(\mathrm{CO})_{5}>\mathrm{Cr}(\mathrm{CO})_{5}>\mathrm{Mo}(\mathrm{CO})_{5}$. The combined consideration of Tables 1 and 2 shows that the importance of backdonation is inversely proportional to the $\delta(\mathrm{Zn}, \mathrm{Zn})$ delocalization indexes, that is to the $\mathrm{Zn}-\mathrm{Zn}$ bond order, and this trend is shown in Fig. S3 (Supplementary Material). The tungsten fragment $\left[\mathrm{W}(\mathrm{CO})_{5}\right]$ appears to be in the limiting situation in which backdonation to the $\mathrm{Zn}-\mathrm{Zn}$ bond causes the disappearance of $\mathrm{CP}$ in the $\left[\left(\mathrm{Zn}_{2} \mathrm{Ph}\right)_{2} \mathrm{~W}(\mathrm{CO})_{5}\right]$ complex. 
Table 2. Average $\mathrm{M} \cdot \mathrm{O}_{\mathrm{CO}}$ and $\mathrm{Pd}-\mathrm{P}$ delocalization indexes.

\begin{tabular}{|l|c|l|c|}
\hline Complex & $\boldsymbol{\delta}(\mathbf{M}, \mathbf{O} \mathbf{c})$ & Complex & $\boldsymbol{\delta}(\mathbf{M}, \mathbf{O} \mathbf{})$ \\
\hline$\left[(\mathrm{ZnCp})_{2} \mathrm{Fe}(\mathrm{CO})_{4}\right]$ & 0.207 & {$\left[(\mathrm{ZnPh})_{2} \mathrm{Fe}(\mathrm{CO})_{4}\right]$} & 0.216 \\
\hline$\left[\left(\kappa^{2}-\mathrm{Zn}{ }_{2} \mathrm{Cp}_{2}\right) \mathrm{Cr}(\mathrm{CO})_{5}\right]$ & 0.168 & {$\left[\left(\kappa^{2}-\mathrm{Zn}_{2} \mathrm{Ph}_{2}\right) \mathrm{Cr}(\mathrm{CO})_{5}\right]$} & 0.170 \\
\hline$\left[\left(\kappa^{2}-\mathrm{Zn}_{2} \mathrm{Cp}_{2}\right) \mathrm{Mo}(\mathrm{CO})_{5}\right]$ & 0.150 & {$\left[\left(\kappa^{2}-\mathrm{Zn}_{2} \mathrm{Ph}_{2}\right) \mathrm{Mo}(\mathrm{CO})_{5}\right]$} & 0.151 \\
\hline$\left[\left(\kappa^{2}-\mathrm{Zn}_{2} \mathrm{Cp}_{2}\right) \mathrm{W}(\mathrm{CO})_{5}\right]$ & 0.177 & {$\left[(\mathrm{ZnPh})_{2} \mathrm{~W}(\mathrm{CO})_{5}\right]$} & 0.179 \\
\hline $\mathbf{C o m p l e x}$ & $\boldsymbol{\delta}(\mathbf{P d}, \mathbf{P})$ & $\mathbf{C o m p l e x}$ & $\boldsymbol{\delta}(\mathbf{P d}, \mathbf{P})$ \\
\hline$\left[\left(\kappa^{2}-\mathrm{Zn}_{2} \mathrm{Cp}_{2}\right) \mathrm{Pd}\left(\mathrm{PF}_{3}\right)_{2}\right]$ & 1.055 & {$\left[(\mathrm{ZnPh})_{2} \mathrm{Pd}\left(\mathrm{PF}_{3}\right)_{2}\right]$} & 1.036 \\
\hline$\left[\left(\kappa^{2}-\mathrm{Zn}_{2} \mathrm{Cp}_{2}\right) \mathrm{Pd}\left(\mathrm{PH}_{3}\right)_{2}\right]$ & 0.988 & {$\left[(\mathrm{ZnPh})_{2} \mathrm{Pd}\left(\mathrm{PH}_{3}\right)_{2}\right]$} & 0.964 \\
\hline$\left[\left(\kappa^{2}-\mathrm{Zn}_{2} \mathrm{Cp}_{2}\right) \mathrm{Pd}\left(\mathrm{PMe}_{3}\right)_{2}\right]$ & 0.962 & {$\left[(\mathrm{ZnPh})_{2} \mathrm{Pd}\left(\mathrm{PMe}_{3}\right)_{2}\right]$} & 0.952 \\
\hline
\end{tabular}

Integration of the electron density over the entire $\mathrm{Zn}-\mathrm{Zn}$ interatomic surface, $\int_{\mathrm{Zn} \cap \mathrm{Zn}} \rho$, can be used to ascertain the strength of the bond. Unfortunately, the method to integrate atomic surface properties in AIMALL fails for complex surfaces, so that the estimation of this integral cannot be done [42]. Notwithstanding, $\int_{\mathrm{M} \cap \mathrm{Zn} \rho}$ can be computed for M-Zn surfaces, thereby shedding light on the characteristics of M-Zn bonds and indirectly on those of the $\mathrm{Zn}-\mathrm{Zn}$ interactions. $\int_{\mathrm{M} \cap \mathrm{Zn}} \rho$ has values in the range $0.646-1.150 \mathrm{e} \cdot \mathrm{bohr}^{-1}$ that are similar to those found for metal-metal bonds in other organometallic compounds [26,27] and smaller, though comparable in magnitude, than those of pure covalent bonds [26]. Except for complexes derived from the $\left[\mathrm{Fe}(\mathrm{CO})_{4}\right]$ fragment, this parameter is lower for $\left[\left(\mathrm{Zn}_{2} \mathrm{Cp}_{2}\right) \mathrm{ML}_{\mathrm{n}}\right]$ derivatives than for the related $\left[\left(\mathrm{Zn}_{2} \mathrm{Ph}_{2}\right) \mathrm{ML}_{n}\right]$. This is also reflected in the $\mathrm{H}_{\mathrm{BCP}} / \rho_{\mathrm{BCP}}$ ratio, which is more negative for $\mathrm{M}-\mathrm{Zn}$ bonds when the $\mathrm{Zn}_{2} \mathrm{Ph}_{2}$ unit is involved. The different behavior of $\left[(\mathrm{ZnR})_{2} \mathrm{Fe}(\mathrm{CO})_{4}\right]$ complexes is due to the absence of $\mathrm{Zn}-\mathrm{Zn}$ interaction.

When $\left[\mathrm{Pd}\left(\mathrm{PR}_{3}\right)_{2}\right]\left(\mathrm{R}=\mathrm{F}, \mathrm{H}\right.$, and $\left.\mathrm{CH}_{3}\right)$ fragments are considered, $\delta(\mathrm{Pd}, \mathrm{Zn})$ delocalization indexes are larger than $\delta(\mathrm{M}, \mathrm{Zn})$ values for $\mathrm{CO}$ containing $\left[\mathrm{M}(\mathrm{CO})_{\mathrm{n}}\right]$ fragments. The reduced $\pi$-acidity of the $\mathrm{PR}_{3}$ ligands, except for $\mathrm{PF}_{3}$, can explain this observation. $\delta(\mathrm{Pd}, \mathrm{Zn})$ values roughly correlate with the $\mathrm{Pd}-\mathrm{Zn}$ bond distance (see Fig. S4). As for the [W(CO) 5 fragment, $\mathrm{Zn}-\mathrm{Zn}$ BCPs are only found for complexes of the $\mathrm{Zn}_{2} \mathrm{Cp}_{2}$ molecule. Consequently, when the $\left[\mathrm{Zn}_{2} \mathrm{Ph}_{2}\right]$ unit is considered the absence of $\mathrm{Zn}-\mathrm{Zn}$ bond gives rise to larger Pd-Zn interactions. This is nicely illustrated by the values of $\int_{\operatorname{Pd} \cap \mathrm{Zn}} \rho$. The tendency of the bond strength is in agreement with the donor/acceptor electron properties of the $\left[\mathrm{Pd}\left(\mathrm{PR}_{3}\right)_{2}\right]$ fragments, which can be also analyzed on the basis of the delocalization index $\delta(\mathrm{Pd}, \mathrm{P})$. The values collected in Table 2 are in agreement with those anticipated, i.e. they are 
higher for the $\mathrm{PF}_{3}$ ligand, followed by $\mathrm{PH}_{3}$ and $\mathrm{PMe}_{3}$. Moreover, these values are higher than those found forr the $\mathrm{M} \cdots \mathrm{O}_{\mathrm{CO}}$ interaction since the $\mathrm{Pd}$ and $\mathrm{P}$ atoms are directly bonded. The lowest $\delta(\mathrm{Pd}, \mathrm{P})$ values correspond to $\mathrm{PMe}_{3}$, in consonance with its good $\sigma$-donor and bad $\pi$-acceptor properties, that additionally result in a reduced $\delta(\mathrm{Zn}, \mathrm{Zn})$ for $\mathrm{Cp}$ and no $\mathrm{Zn}$ - $\mathrm{Zn}$ bond for $\mathrm{Ph}$. By contrast, the highest $\delta(\mathrm{Pd}, \mathrm{P})$ obtained for the excellent $\pi$-acceptor ligand $\mathrm{PF}_{3}$ in the $\left[\mathrm{Zn}_{2} \mathrm{Cp}_{2}\right]$ complex results in higher $\delta(\mathrm{Zn}, \mathrm{Zn})$ value and shorter $\mathrm{Zn}$ - $\mathrm{Zn}$ distance, relative to $\mathrm{PH}_{3}$ and $\mathrm{PMe}_{3}$. As already stated, the decrease in the $\mathrm{Zn}-\mathrm{Zn}$ bond order implies a concomitant increase in the strength of the M-Zn bond, such that for Pd complexes there is a fair correlation between the $\mathrm{Zn} \cdots \mathrm{Zn}$ separation and the Pd-Zn bond distances (see Fig. S5). Taking this fact into account, the $\delta(\mathrm{Pd}, \mathrm{P})$ values can also be related to the $\mathrm{Pd}-\mathrm{Zn}$ bond distances, to the point that, as shown in Fig. 6, there exists a good correlation between these parameters.

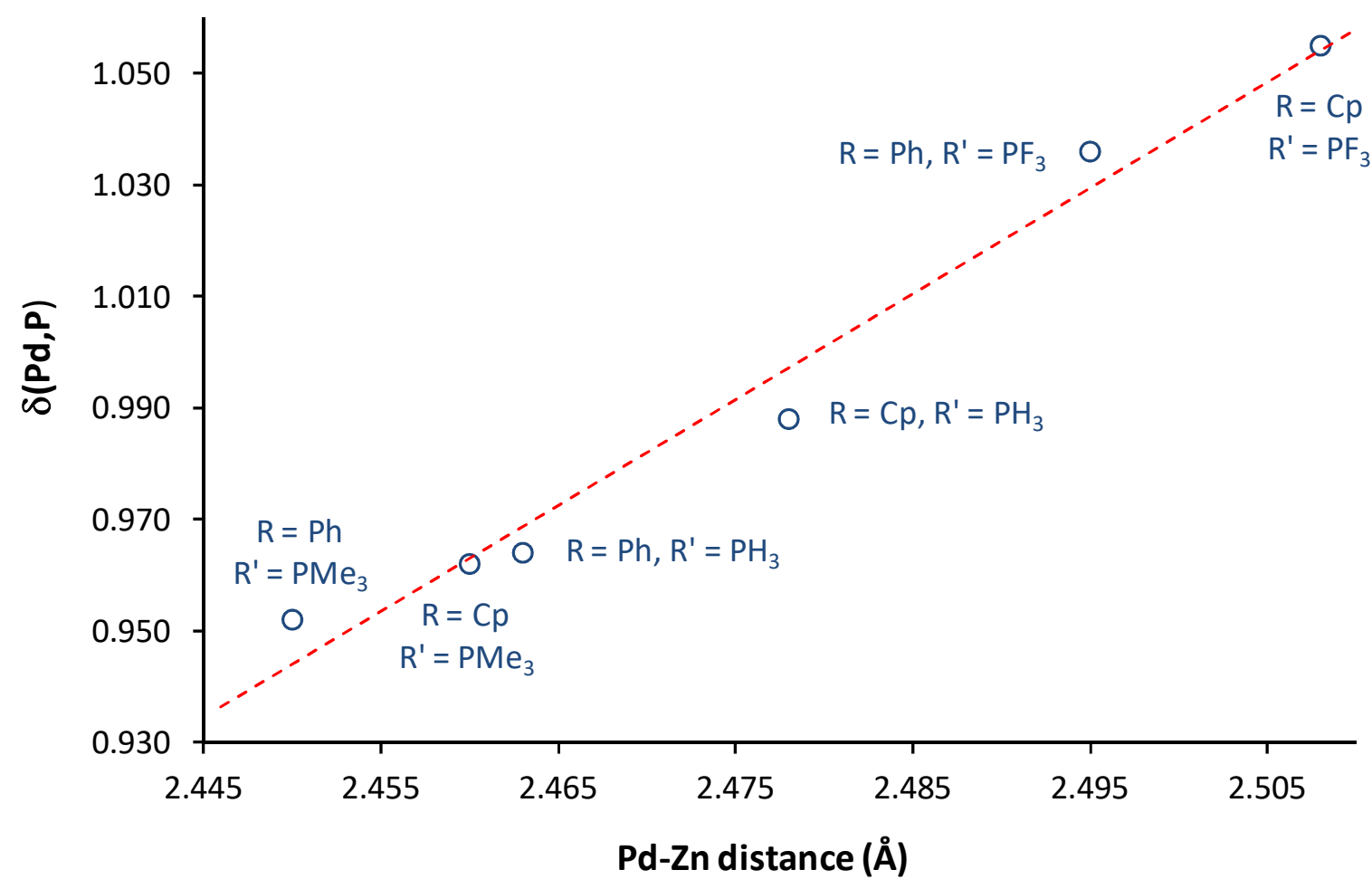

Fig. 6. Relationship between the delocalization index $\delta(\mathrm{Pd}, \mathrm{P})$ and the computed $\mathrm{Pd}-\mathrm{Zn}$ bond distances for $\left[\left(\mathrm{Zn}_{2} \mathrm{R}_{2}\right) \mathrm{Pd}\left(\mathrm{PR}_{3}\right)_{2}\right]$ complexes.

In complexes containing M-Zn and $\mathrm{Zn}-\mathrm{Zn}$ bonds, $\mathrm{Zn}-\mathrm{M}-\mathrm{Zn}$ ring critical points (RCPs) can also be identified, proving the delocalization of electron density among the three centres. The bond path lengths are similar to the interatomic distances for M-Zn bonds, and larger for 
$\mathrm{Zn}-\mathrm{Zn}$ interactions. The latter present inwardly curved $\mathrm{Zn}-\mathrm{Zn}$ bond paths (see the topological graphs in Fig. S2). The $\varepsilon_{B C P}$ values associated to the $\mathrm{Zn}-\mathrm{Zn}$ bond paths in $\left[\left(\mathrm{Zn}_{2} \mathrm{R}_{2}\right) \mathrm{ML}_{\mathrm{n}}\right]$ complexes are greater than zero in all cases, implying the existence of a $\pi$-component of the bonding that was absent in the parent molecules of $\left[\mathrm{Zn}_{2} \mathrm{Cp}_{2}\right]$ and $\left[\mathrm{Zn}_{2} \mathrm{Ph}_{2}\right]$. The bond ellipticity decreases when going from $\left[\left(\mathrm{Zn}_{2} \mathrm{Cp}_{2}\right) \mathrm{ML}_{n}\right]$ to $\left[\left(\mathrm{Zn}_{2} \mathrm{Ph}_{2}\right) \mathrm{ML}_{n}\right]$ complexes. This observation can be interpreted as a tendency to break the $\mathrm{Zn}-\mathrm{Zn}$ bond, consequently opening the $\mathrm{Zn}-\mathrm{M}-\mathrm{Zn}$ ring. The sensitivity of the structure to ring opening is quantitatively described by the bond ellipticity value $\varepsilon_{\mathrm{BCP}}$, which becomes larger for the more unstable structures [25]. Structure instability means that small energy is required to cause the migration of RCP to BCP with high ellipticity, which inevitably leads to a bifurcation catastrophe (the formation of degenerate critical points) and disappearance of the ring [43]. It is reasonable to believe that the closer the ring and bond critical points, with high ellipticity, the potentially more unstable the structure will become. The analysis of the position of Zn-M-Zn RCPs and Zn-Zn BCP shows that the bonds with high $\varepsilon_{\mathrm{BCP}}$ are very close to one another (Fig. S2), once again manifesting the higher stability of complexes $\left[\left(\mathrm{Zn}_{2} \mathrm{Cp}_{2}\right) \mathrm{ML}_{n}\right]$ compared to $\left[\left(\mathrm{Zn}_{2} \mathrm{Ph}_{2}\right) \mathrm{ML}_{n}\right]$.

The $\delta(\mathrm{Zn}, \mathrm{Zn})$ delocalization indexes can also be estimated for the non-bonding $\mathrm{Zn} \cdots \mathrm{Zn}$ interactions (in parenthesis in Table 1), contributing additionally to clarify the main features of these interaplays. Although smaller than for bonded atoms, their estimated values are by no means negligible, except for the iron complexes $\left[(\mathrm{ZnR})_{2} \mathrm{Fe}(\mathrm{CO})_{4}\right](\mathrm{R}=\mathrm{Cp}, \mathrm{Ph})$. Rather, they are comparable in magnitude to values found for bonded $\mathrm{Zn}-\mathrm{Zn}$ atoms and for metal-metal interactions in other organometallic compounds $[26,27,41 \mathrm{a}, \mathrm{b}]$. This means that, although very delocalized, there exists a $\mathrm{Zn}-\mathrm{Zn}$ interaction in all cases studied except for $\left[(\mathrm{ZnR})_{2} \mathrm{Fe}(\mathrm{CO})_{4}\right](\mathrm{R}=\mathrm{Cp}, \mathrm{Ph})$ complexes, where the long $\mathrm{Zn}$ - Zn distances, along with the important $\mathrm{Fe}-\mathrm{CO} \pi$-backbonding preclude any possible interaction.

\section{Conclusions}

A QTAIM study of the bonding capabilities of model complexes $\left[\mathrm{Zn}_{2} \mathrm{Cp}_{2}\right]$ and [ $\left.\mathrm{Zn}_{2} \mathrm{Ph}_{2}\right]$, when they act as $\eta^{2}-\mathrm{Zn}_{2}$-ligands in selected metal fragments, has been carried out. The studied metal fragments are $\left[\mathrm{Fe}(\mathrm{CO})_{4}\right]\left(\mathrm{d}^{8}-\mathrm{ML}_{4}\right),\left[\mathrm{M}(\mathrm{CO})_{5}\right]$ for $\mathrm{M}=\mathrm{Cr}, \mathrm{Mo}, \mathrm{W}\left(\mathrm{d}^{6}-\mathrm{ML}_{5}\right)$ and $\left[\mathrm{Pd}\left(\mathrm{PR}_{3}\right)_{2}\right)_{2}$ for $\mathrm{R}^{\prime}=\mathrm{F}, \mathrm{H}, \mathrm{Me}\left(\mathrm{d}^{10}-\mathrm{ML}_{2}\right)$. They are characterized by an empty $\sigma$ hybrid and a filled $\pi$ hybrid orbitals, topologically matched for synergic bonding-backbonding 
interactions with the $\left[\mathrm{Zn}_{2} \mathrm{R}_{2}\right]$ complex. An analysis of the preservation of the $\mathrm{Zn}-\mathrm{Zn}$ interaction after coordination of the dizinc moiety to the transition metal fragment has been undertaken. In all the cases, the values of $\rho_{\mathrm{BCP}}, \nabla^{2} \rho_{\mathrm{BCP}}$ and of the delocalization indexes $\delta(\mathrm{Zn}, \mathrm{Zn})$ decrease in comparison with their original values in the parent $\left[\mathrm{Zn}_{2} \mathrm{Cp}_{2}\right]$ and $\left[\mathrm{Zn}_{2} \mathrm{Ph}_{2}\right]$ molecules. The combination of the different fragments introduces asymmetry and polarity within the $\mathrm{Zn}-\mathrm{Zn}$ bonds, along with a variation of the electronic environment at the two $\mathrm{Zn}$ centres that alters the $\mathrm{Zn}-\mathrm{Zn}$ interaction. Nevertheless, the delocalization indexes $\delta(\mathrm{Zn}, \mathrm{Zn})$ indicate significant electron pair sharing between $\mathrm{Zn}$ centres for all but the $\left[\mathrm{Fe}(\mathrm{CO})_{4}\right]$ fragment, where the high backdonation (computed through the $\delta\left(\mathrm{M}, \mathrm{O}_{\mathrm{CO}}\right)$ index) to the $\sigma^{*}$ dizinc MO produces the oxidative cleavage of the dizinc bond. The dizinc complexes that show a critical point in the $\mathrm{Zn}-\mathrm{Zn}$ path have distances within the $2.44-2.58 \AA$ range. In analogy with the dihydrogen molecule, we suggest this as a new range for elongated dizinc bonds. The $\delta(\mathrm{Zn}, \mathrm{Zn})$ delocalization index is larger for $\left[\left(\mathrm{Zn}_{2} \mathrm{Cp}_{2}\right) \mathrm{ML}_{\mathrm{n}}\right]$ than for $\left[\left(\mathrm{Zn}_{2} \mathrm{Ph}_{2}\right) \mathrm{ML}_{\mathrm{n}}\right]$ complexes, and the opposite variation was observed for $\delta(\mathrm{M}, \mathrm{Zn})$. This is a general trend that correlates the decrease in the $\mathrm{Zn}-\mathrm{Zn}$ bond order with the concomitant increase in the $\mathrm{M}-\mathrm{Zn}$ bond order (measured by $\int_{\mathrm{M} \cap \mathrm{Zn} \rho} \rho$ ). The influence of the donor/acceptor properties of the coligands is clearly observed when complexes $\left[\left(\mathrm{Zn}_{2} \mathrm{R}_{2}\right) \mathrm{Pd}\left(\mathrm{PR}_{3}\right)_{2}\right]$ are analyzed, for the excellent $\pi$-acceptor $\mathrm{PF}_{3}$ (measured by the $\delta(\mathrm{Pd}, \mathrm{P})$ index) affords higher $\delta(\mathrm{Zn}, \mathrm{Zn})$ values and shorter $\mathrm{Zn}-\mathrm{Zn}$ distances than the better donnors $\mathrm{PH}_{3}$ and $\mathrm{PMe}_{3}$. None of the investigated $\left[\left(\mathrm{Zn}_{2} \mathrm{R}_{2}\right) \mathrm{ML}_{\mathrm{n}}\right]$ complexes have been experimentally synthesized. However, after the report by Fisher, Frenking and coworkers of examples in which the dizinc unit act as a ligand, particularly the complex $\left[\left(\mathrm{Zn}_{2} \mathrm{Cp} * \mathrm{Me}\right) \mathrm{Ni}\left(\mathrm{PMe}_{3}\right)_{3}\right]$, some of the computed models could be considered rational experimental targets. It is reasonable to believe that the present computational study will provide theoretical insights for future preparations of $\eta^{2}-Z n_{2}$ complexes in which the dizinc ligand resembles the dihydrogen ligand.

\section{Acknowledgements}

Financial support from the Junta de Andalucía (Proyecto de Excelencia FQM-7079 and FQM-282 group) and the Spanish Ministerio de Ciencia e Innovacion (CTQ2011-25932) are gratefully acknowledged. Authors thank the Centro de Servicios de Informática y Redes 
de Comunicaciones (CSIRC), Universidad de Granada, and FQM-282 in-house facilities for providing the computing time.

\section{Appendix A. Supplementary material}

Supplementary data associated with this article can be found, in the online version, at http://dx.doi.org/ 


\section{References}

1 I. Resa, E. Carmona, E. Gutiérrez Puebla, A. Monge, Science 305 (2004) 1136.

2 A. Grirrane, I. Resa, A. Rodríguez, E. Carmona, E. Álvarez, E. Gutiérrez-Puebla, A. Monge, A. Galindo, D. del Río, R. H. Andersen, J. Am. Chem. Soc. 129 (2007) 693.

3 (a) E. Carmona, A. Galindo, Angew. Chem., Int. Ed. 47 (2008) 6526; (b) A. Grirrane, I. Resa, A. Rodríguez, E. Carmona, Coord. Chem. Rev. 252 (2008) 1532.

4 T. Li, S. Schulz, P. W. Roesky, Chem. Soc. Rev. 41 (2012) 3759.

5 D. del Río, A. Galindo, I. Resa, E. Carmona, Angew. Chem., Int. Ed. 44 (2005) 1244.

6 Selected examples: (a) Y. Xie, H. F. Schaefer III, R. B. King, J. Am. Chem. Soc. 127 (2005) 2818. (b) H. S. Kang, J. Phys. Chem. A 109 (2005) 4342. (c) Z.-Z. Xie, W. H. Fang, Chem. Phys. Lett. 404 (2005) 212. (d) J. W. Kress, J. Phys. Chem. A 109 (2005) 7757. (e) S. L. Richardson, T. Barnah, M. R. Pederson, Chem. Phys. Lett. 415 (2005) 141. (f) Z.-Z. Liu, W. Q. Tian, J.-K. Feng, G. Zhang, W.-Q. Li, J. Mol. Struct. 758 (2006) 127. (g) M. R. Philpott, Y. Kawazoe, Chem. Phys. 327 (2006) 283. (h) M. R. Philpott, Y. Kawazoe, J. Mol. Struct. 773 (2006) 43. (i) M. R. Philpott, Y. Kawazoe, J. Mol. Struct. 776 (2006) 113. (j) H. Wang, C. Yang, B. Wan, K.-L. Han, J. Theor. Comput. Chem. 5 (2006) 461. (l) K. K. Pandey, J. Organomet. Chem. 692 (2007) 1058. (m) M. R. Philpott, Y. Kawazoe, Chem. Phys. 333 (2007) 201. (n) Y. Kan, J. Mol. Struct. 805 (2007) 127.

7 D. del Río, I. Resa, A. Rodríguez, L. Sánchez, R. Köppe, A. J. Downs, C. Y. Tang, E. Carmona, J. Phys. Chem. 112 (2008) 10516.

8 J. F. van der Maelen, E. Gutiérrez-Puebla, A. Monge, S. García-Granda, I. Resa, E. Carmona, M. T. Fernández-Díaz, G. J. McIntyre, P. Pattison, H.-P. Weber, Acta Cryst. B63 (2007) 862.

9 (a) Z. Zhu, R. J. Wright, M. M. Olmstead, E. Rivard, M. Brynda, P. P. Power, Angew. Chem., Int. Ed. 45 (2006) 5807; (b) Z. Zhu, M. Brynda, R. J. Wright, R. C. Fischer, W. A. Merrill, E. Rivard, R. Wolf, J. C. Fettinger, M. M. Olmstead, P. P. Power, J. Am. Chem. Soc. 129 (2007) 10847; (c) Z. Zhu, J. C. Fettinger, M. M. Olmstead, P. P. Power, Organometallics 28 (2009) 1590.

10 (a) Y. Wang, B. Quillian, P. Wei, H. Wang, X.-J. Yang, Y. Xie, R. B. King, P. V. R. Schleyer, H. F. Schaefer III, G. H. Robinson, J. Am. Chem. Soc. 127 (2005) 11944; (b) I. L. Fedushkin, A. A. Skatova, S. Y. Ketkov, O. V. Eremenko, A. V. Piskunov, G. K. Fukin, Angew. Chem., Int. Ed. 46 (2007) 4302; (c) I. L. Fedushkin, O. V. Eremenko, A. A. Skatova, A. V. Piskunov, G. K. Fukin, S. Y. Ketkov, Organometallics 28 (2009) 3863. 
(a) X.-J. Yang, J. Yu, Y. Liu, Y. Xie, H. F. Schaefer III, Y. Liang, B. Wu, Chem. Commun. 2007, 2363; (b) Y.-C. Tsai, D.-Y. Lu, Y.-M. Lin, J.-K. Hwang, J.-S. K. Yub, Chem. Commun. 2007, 4125. (c) J. Yu, X.-J. Yang, Y. Liu; Z. Pu, Q.-S. Li, Y. Xie, H. F. Schaefer III, B. Wu, Organometallics 27 (2008) 5800.

12 (a) Y. Liu, S. Li, X.-J. Yang, P. Yang, J. Gao, Y. Xia, B. Wu, Organometallics 28 (2009) 5270; (b) P. Yang, X.-J. Yang, J. Yu, Y. Liu, C. Zhang, Y.-H. Deng, B. Wu, Dalton Trans. (2009) 5773; (c) A. Stasch, Chem. Eur. J. 18 (2012) 15105; (d) J. Gao, S. Li, Y. Zhao, B. Wu, X.-J. Yang, Organometallics 31 (2012) 2978; (e) J. Hicks, E. J. Underhill, C. E. Kefalidis, L. Maron, C. Jones, Angew. Chem., Int. Ed. 54 (2015) 10000. S. Schulz, D. Schuchmann, I. Krossing, D. Himmel, D. Bläser, R. Boese, Angew. Chem., Int. Ed. 48 (2009) 5748.

14 K. Freitag, H. Banh, C. Gemel, P. Jerabek, R. W. Seidel, G. Frenking, R. A. Fischer, Inorg. Chem. 54 (2015) 352-358.

15 (a) D. Schuchmann, U. Westphal, S. Schulz, U. Flörke, D. Bläser, R. Boese, Angew. Chem., Int. Ed. 48 (2009) 807; (b) S. Schulz, D. Schuchmann, U. Westphal, M. Bolte, Organometallics 28 (2009) 1590; (c) S. Schulz, S. Gondzik, D. Schuchmann, U. Westphal, L. Dobrzycki, R. Boese, S. Harder, Chem. Commun. 46 (2010) 7757; (d) S. Gondzik, D. Bläser, C. Wölper, S. Schulz, Chem. Eur. J. 16 (2010) 13599; (e) H. P. Nayek, A. Lühl, S. Schulz, R. Köppe, P. W. Roesky, Chem. Eur. J. 17 (2011) 1773; (f) S. Gondzik, S. Schulz, D. Blaser, C. Wölper, R. Haack, G. Jansen, Chem. Commun. 50 (2014) 927 (g) S. Gondzik, S. Schulz, D. Blaser, C. Wölper, Chem. Commun. 50 (2014) 1189.

16 A. Lühl, L. Hartenstein, S. Blechert, P. Roesky, Organometallics 31 (2012) 7109.

17 (a) T. Bollermann, K. Freitag, C. Gemel, M. Molon, R. W. Seidel, P. Jerabek, G.

Frenking, R. A. Fischer, Inorg. Chem. 50 (2011) 10486; (b) T. Bollermann, K. Freitag, C. Gemel, R. W. Seidel, R. A. Fischer, Organometallics 30 (2011) 4123; (c) T. Bollermann, K. Freitag, C. Gemel, R. W. Seidel, M. von Hopffgarten, G. Frenking, R. A. Fischer, Angew. Chem. Int. Ed. 50 (2011) 772.

18 (a) K. Freitag, H. Banh, C. Ganesamoorthy, C. Gemel, R. W. Seidel, R. A. Fischer, Dalton Trans. 42 (2013) 10540; (b) K. Freitag, H. Banh, C. Gemel, R. W. Seidel, S. Kahlal, J.Y. Saillard, R. A. Fischer, Chem. Commun. 50 (2014) 8681; (c) K. Mayer, L.-A. Jantke, S. Schulz, T. Fässler, Angew. Chem. Int. Ed. 56 (2017) 2359-2355.

19 T. Bollermann, C. Gemel, R. A. Fischer, Coord. Chem. Rev. 256 (2012) 537. 
(a) R. F. W. Bader, Atoms in Molecules: A Quantum Theory; Oxford University Press: Oxford, 1990. (b) R. F. W. Bader, Monatsh. Chem. 136 (2005) 819-854. (c) R. F. W. Bader, Chem. Rev. 91 (1991) 893-928. (d) F. Cortés-Guzmán, R. F. W. Bader, Coord. Chem. Rev. 249 (2005) 633-662. (e) P. L. A. Popelier, Atoms in Molecules: An Introduction; Prentice Hall: London, 2000.

21 (a) R. F. Bader, H. Essen, J. Chem. Phys. 80 (1984) 1943. (b) D. Cremer, E. Kraka, Croat. Chem. Acta, 1984 1259. (c) D. Cremer, E. Kraka, Angew. Chem. Int. Engl. Ed. 23 (1984) 67.

(a) P. Macchi, D. M. Proserpio, A. Sironi, J. Am. Chem. Soc. 120 (1998) 13429-13435.

(b) P. Macchi, L. Garlaschelli, A. Sironi, J. Am. Chem. Soc. 124 (2002) 14173-14184. (c)

C. Gatti, Z. Kristallogr. 220 (2005) 399-457.

23 E. Espinosa, I. Alkorta, J. Elguero, E. Molins, J. Chem. Phys. 117 (2002) 5529.

24 G. Gervasio, R. Bianchi, D. Marabello, Chem. Phys. Lett. 387 (2004) 481-484.

25 R. F. W. Bader, T. S. Slee, D. Cremer, and E. Kraka, J. Am. Chem. Soc ., 105 , No. 15, $5061(1983)$

P. Macchi, A. Sironi, Coord. Chem. Rev. 238- 239 (2003) 383-412.

C. Gatti, Z. Kristallogr. 220 (2005) 399-457.

K. Freitag, M. Molon, P. Jerabek, K. Dilchert, C. Rösler, R. W. Seidel, C. Gemel, G. Frenking, R. A. Fischer, Chem. Sci. 7 (2016) 6413.

(a) A. D. Becke, Phys. Rev. A: Gen. Phys. 38 (1988) 3098-100. (b) J. P. Perdew, Phys. Rev. B 33 (1986) 8822-8824.

(a) F. Weigend, R. Ahlrichs, Phys. Chem. Chem. Phys. 7 (2005) 3297-305. (b) F.

Weigend, Phys. Chem. Chem. Phys. 8 (2006) 1057-65.

31 (a) S. J. Grimme, Comput. Chem. 27 (2006) 1787-1799. (b) S. Grimme, J. Antony, S. Ehrlich, H. J. Krieg, Chem. Phys. 132 (2010) 154104/1-154104/19.

32 (a) W. R. Wadt, P. J. Hay, J. Chem. Phys. 82 (1985) 284-98. (b) P. J. Hay, W. R. Wadt, J. Chem. Phys. 82 (1985) 299-310.

33 See for example: (a) A. Lignell, L. Khriachtchev, M. Räsänen, M. Pettersson, Chem. Phys. Lett. 390 (2004) 256. (b) J. van Slageren, A. Klein, S. Zalis, D. Stufkens, J. Coord. Chem. Rev. 219-221 (2001) 937.

34 Gaussian 09, Revision D.01, M. J. Frisch, G. W. Trucks, H. B. Schlegel, G. E. Scuseria, M. A. Robb, J. R. Cheeseman, G. Scalmani,V. Barone, B. Mennucci, G. A. Petersson, H. Nakatsuji, M. Caricato, X. Li, H. P. Hratchian, A. F. Izmaylov, J. Bloino, G. Zheng, J. L. 
Sonnenberg, M. Hada, M. Ehara, K. Toyota, R. Fukuda, J. Hasegawa, M. Ishida, T.

Nakajima, Y. Honda, O. Kitao, H. Nakai, T. Vreven, J. A. Montgomery,Jr., J. E. Peralta, F. Ogliaro, M. Bearpark, J. J. Heyd, E. Brothers, K. N. Kudin, V. N. Staroverov, R. Kobayashi, J. Normand, K. Raghavachari, A. Rendell, J. C. Burant, S. S. Iyengar, J. Tomasi, M. Cossi, N. Rega, J. M. Millam, M. Klene, J. E. Knox, J. B. Cross, V. Bakken, C. Adamo, J. Jaramillo, R. Gomperts, R. E. Stratmann, O. Yazyev, A. J. Austin, R. Cammi, C. Pomelli, J. W. Ochterski, R. L. Martin, K. Morokuma, V. G. Zakrzewski, G. A. Voth, P. Salvador, J. J. Dannenberg, S. Dapprich, A. D. Daniels, Ö. Farkas, J. B. Foresman, J. V. Ortiz, J. Cioslowski, D. J. Fox, Gaussian, Inc., Wallingford CT, 2009. AIMALL (Version 12.06.05), T. A. Keith, TK Gristmill Software, Overland Park KS, USA, 2012.

Cambridge Structural Database System, Cambridge Crystallographic data Centre, 12 Union Road, Cambridge, CB2 1EZ, UK. C. R. Groom, I. J. Bruno, M. P. Lightfoot, S. C. Ward, Acta Crystallogr. B72 (2016) 171-179.

K. Freitag, C. Gemel, P. Jerabek, I. M. Oppel, R. W. Seidel, G. Frenking, H. Banh, K. Dilchert, R. A. Fischer, Angew. Chem. Int. Ed. 54 (2015) 4370-4374. (2010) 778. (b) U. Jayarathne, T. J. Mazzacano, S. Bagherzadeh, N. P. Mankad, Organometallics 32 (2013) 3986. (c) T. J. Mazzacano, N. P. Mankad, J. Am. Chem. Soc. 135 (2013) 17258. (d) M. P. Blake, N. Kaltsoyannis, P. Mountford, Chem. Commun. 51 (2015) 5743.

J. Meyer, S. González-Gallardo, S. Hohnstein, D. Garnier, M. K. Armbruster, K. Fink, W. Klopper, F. Breher, Chem. Eur. J. 21 (2015) 2905-2914. (2008) 9146. (b) T. Cadenbach, T. Bollermann, C. Gemel, I. Fernandez, M. von Hopffgarten, G. Frenking, R. A. Fischer, Angew. Chem. Int. Ed. 47 (2008) 9150. (c) T. Cadenbach, T. Bollermann, C. Gemel, M. Tombul, I. Fernandez, M. von Hopffgarten, G. Frenking, R. A. Fischer, J. Am. Chem. Soc. 131 (2009) 16063. (d) T. Bollermann, T. Cadenbach, C. Gemel, M. von Hopffgarten, G. Frenking, R. A. Fischer, Chem. Eur. J. 16 (2010) 13372.

41 See for example: (a) J. F. Van der Maelen, S. García-Granda, J. A. Cabeza, Comput. Theor. Chem. 968 (2011) 55-63. (b) J. A. Cabeza, J. F. Van der Maelen, S. García- 
Granda, Organometallics 28 (2009) 3666. (c) J. F. Van der Maelen, J. A. Cabeza, Theor. Chem. Acc. 135 (2016) 64.

42 Interatomic surface properties are currently only calculable using the "Proaim" integration method. In some cases, this method fails due to the atomic surfaces complexity and another method ("Promega") must be used for which basin properties are calculable but not atomic surface properties.

43 R. Krishnan, J. S. Binkley, R. Seeger, J. A. Pople, J. Chem. Phys. 72 (1980) 650. 